\title{
Arctic aerosol life cycle: linking aerosol size distributions observed between 2000 and 2010 with air mass transport and precipitation at Zeppelin station, Ny-Ålesund, Svalbard
}

\author{
P. Tunved, J. Ström, and R. Krejci \\ Department of Applied Environmental Science (ITM), Stockholm University, 11418 Stockholm, Sweden \\ Correspondence to: P. Tunved (peter.tunved@itm.su.se)
}

Received: 21 September 2012 - Published in Atmos. Chem. Phys. Discuss.: 21 November 2012

Revised: 28 February 2013 - Accepted: 12 March 2013 - Published: 2 April 2013

\begin{abstract}
In this study we present a qualitative and quantitative assessment of more than $10 \mathrm{yr}$ of aerosol number size distribution data observed in the Arctic environment (Mt. Zeppelin ( $78^{\circ} 56^{\prime} \mathrm{N}, 11^{\circ} 53^{\prime} \mathrm{E}, 474 \mathrm{~m}$ a.s.1.), Ny Ålesund, Svalbard). We provide statistics on both seasonal and diurnal characteristics of the aerosol observations and conclude that the Arctic aerosol number size distribution and related parameters such as integral mass and surface area exhibit a very pronounced seasonal variation. This seasonal variation seems to be controlled by both dominating source as well as meteorological conditions. Three distinctly different periods can be identified during the Arctic year: the haze period characterized by a dominating accumulation mode aerosol (March-May), followed by the sunlit summer period with low abundance of accumulation mode particles but high concentration of small particles which are likely to be recently and locally formed (June-August). The rest of the year is characterized by a comparably low concentration of accumulation mode particles and negligible abundance of ultrafine particles (September-February). A minimum in aerosol mass and number concentration is usually observed during September/October.

We further show that the transition between the different regimes is fast, suggesting rapid change in the conditions defining their appearance. A source climatology based on trajectory analysis is provided, and it is shown that there is a strong seasonality of dominating source areas, with Eurasia dominating during the Autumn-Winter period and dominance of North Atlantic air during the summer months. We also show that new-particle formation events are rather common phenomena in the Arctic during summer, and this is the
\end{abstract}

result of photochemical production of nucleating/condensing species in combination with low condensation sink. It is also suggested that wet removal may play a key role in defining the Arctic aerosol year, via the removal of accumulation mode size particles, which in turn have a pivotal role in facilitating the conditions favorable for new-particle formation events. In summary the aerosol Arctic year seems to be at least qualitatively predictable based on the knowledge of seasonality of transport paths and associated source areas, meteorological conditions and removal processes.

\section{Introduction}

The Arctic environment is well known to be particularly sensitive to perturbations of the radiative budget. During the last century the temperature increase in the Arctic has been observed to be two times larger than the global average (IPCC, 2007). The reason for this "Arctic amplification" relates to both the complex feedbacks that are active in the Arctic environment as well as the overall environmental conditions that are characteristic of the Arctic environment. This increased warming results in, for example, an earlier onset of sea ice melt and ice loss in general, through which positive feedback further impacts the radiative balance via reduced surface albedo (Hudson, 2011; Robock, 1983). Future changes in the Arctic are projected to progress rapidly. Several studies have suggested that the Arctic Ocean may be seasonally ice free in the next 30-40 yr (Serreze et al., 2007; Wang and Overland, 2009). This will also have a larger impact on 
atmospheric aerosol sources and sinks as well as on cloud properties and cloud distribution in the region.

Aerosols are key constituents of the atmosphere, and they belong to a group of trace constituents called short-lived pollutants (SLPs). Aerosol particles are believed to perturb the radiative balance of the Arctic environment in numerous ways. During the last three decades the Arctic environment has experienced a warming of $1.48 \pm 0.28^{\circ} \mathrm{C}$. Of this warming, $1.09 \pm 0.81{ }^{\circ} \mathrm{C}$ has been attributed to changes in aerosol forcing (Shindell and Faluvegi, 2009). The climatic influence of aerosol particles is a result of their ability to both directly scatter and absorb incoming shortwave solar radiation (Charlson et al., 1992). The former is assumed to result in a net cooling of the lower atmosphere and surface, while the latter may cause warming of the atmosphere and subsequently also the surface due to increased down welling of long-wave radiation. Recent studies do, however, suggest that this mechanism also may induce dynamic feedbacks that still lead to a net cooling of the surface due to weakening of lateral temperature gradients (Sand et al., 2013). All in all, the ratio between scattering and absorbing chemical species, as well as particle size and their abundance, properties of underlying surfaces and meteorological conditions, will ultimately determine the magnitude of the aerosolinduced direct forcing. Furthermore, aerosols also constitute the seeds upon which cloud droplets form. Changes in the aerosol chemistry and abundance will indirectly affect the cloud microphysical properties (Twomey, 1977) and lifetime (Albrecht, 1989). The net effect of altered aerosol-cloud interactions over the Arctic remains uncertain and will naturally vary with season and location (Lubin and Vogelmann, 2010; Hu et al., 2005). The Arctic is a complex environment where, as opposed to large parts of the world, the typical cloud properties together with bright ice and snow-covered surfaces cause clouds to actually warm the surface by more efficiently trapping and re-emitting a portion of the outgoing long-wave radiation in the Arctic (Shupe and Intrieri, 2004; Garrett et al., 2002). High sun and dark surfaces will favor shortwave forcing (i.e. during the summer period), whereas bright surfaces and low sun or darkness will favor the longwave radiation forcing (i.e. during the winter period).

Furthermore, absorbing species, such as soot, may boost surface heating and ice melting by decreasing the surface albedo when deposited on snow and ice (Rosen et al., 1981; Clarke and Noone, 1985; Hansen and Nazarenko, 2004; Flanner et al., 2007).

As indicated above, aerosols may substantially impact the radiative budget of the Arctic environment. Improved understanding of the spatial and temporal variability of the microphysical properties of the aerosol in the Arctic is required in order to determine the magnitude and direction of future climate change in this important region.

The Arctic aerosol has been shown to be highly variable over the year (e.g. Strom et al., 2003). A prime example is the Arctic spring period when elevated levels of aerosols and trace gases largely define the matrix of atmospheric trace constituents. This annually re-occurring phenomenon is called Arctic haze and was first observed in the 1950s during routine flights over the Arctic (Mitchell, 1956). With its comparably high concentration of accumulation mode size particles and mass, the Arctic haze period is in sharp contrast to the otherwise clean Arctic air (Shaw, 1995). The elevated particle and gas concentrations originate from lower latitudes, which - as a result of strong inversions, hindered vertical mixing and a lack of formation of cloud systems, reduced removal by precipitation together with atmospheric blocking phenomena - are allowed to be transported into the Arctic region (Iversen and Joranger, 1985; Shaw, 1981). The haze particles mainly consist of sulphates, different organic constituents, as well as soot and other trace elements, reflecting their anthropogenic origin (Quinn et al., 2007; Heintzenberg et al., 1981). Elevated concentrations of the above-mentioned particles are often associated with increased concentrations of sulphur dioxide, nitric acid or PANs (Peroxy Acyl Nitrates) (Jaeschke et al., 1997, 1999).

It is still debated as to how different natural and anthropogenic source regions contribute to the Arctic aerosol. Several studies on the topic have been performed utilizing transport climatologies and various statistical methods. In a recent study (Hirdman et al., 2010) the importance of source regions in characterizing some key SLPs at three Arctic sites (Barrow, Zeppelin and Alert) was investigated. The dominating sources of sulphate aerosols and equivalent black carbon to the Arctic during winter were argued to be located in northern parts of Eurasia. During summertime, sources in Siberia and North America give important contributions to the Arctic aerosol. The importance of biomass burning in Russia, Siberia and Kazakhstan as a contributor to high springtime aerosol loadings (i.e. the haze period) in the Arctic has previously been demonstrated (Warneke et al., 2009). Eastern European agricultural fires were responsible also for record high air pollution levels in the European Arctic observed in spring 2006 (Stohl et al., 2007). No direct evidence of contribution of black carbon (BC) from Asia or southern North America has been reported at surface sites within the Arctic, although these areas could possibly contribute sulphur to the Arctic. Influence at higher altitudes can not be ruled out, however. Other studies of long-term transport climatology include the works of (Brock et al., 2011; Fisher et al., 2010; Polissar et al., 1998, 2001; Stohl, 2006).

During the beginning of the summer period, changes in the general circulation, increased presence of low-level clouds (and thus more effective wet removal) result in rather fast clean up after the haze period. Lower aerosol loading, increased photochemistry and biological activity results in a peak in new particle formation during the Arctic summer (Strom et al., 2009; Engvall et al., 2008b). Where and how the new particle formation predominantly occurs is still under debate. Observations show new particle formation to be taking place at both higher altitudes including free 
troposphere (Weber et al., 2003; Khosrawi et al., 2010; Hegg et al., 1995) as well as in the boundary layer near the surface (Strom et al., 2009). Occasionally long-range transport pollution events also occur during the summer (Iziomon et al., 2006; O'Neill et al., 2008). Contrary to the summer, the Arctic winter period is devoid of sunlight. This reduces photochemical production and new particle formation to a minimum, and both concentration and variability of aerosols are typically low.

In this study we provide a compilation of ten years of aerosol number size distribution observations and characterize these with respect to seasonal and diurnal variations and influence of source regions. We investigate and discuss the role of different processes controlling the aerosol size distribution on longer and shorter temporal scales. By performing trajectory analysis and transport statistics, we provide an explanation to the variability of the aerosol number size distribution as observed at Mt. Zeppelin in terms of atmospheric aerosol sources, sinks and transformation processes.

\section{Methods}

\subsection{Aerosol observations at Mt. Zeppelin}

The aerosol number size distribution observations that are presented in this study were collected at the Zeppelin observatory located on the top of Mt. Zeppelin, Svalbard $\left(78^{\circ} 56^{\prime} \mathrm{N}, 11^{\circ} 53^{\prime} \mathrm{E}, 474 \mathrm{~m}\right.$ a.s.l.), just outside the small community of Ny Ålesund. The station represents remote Arctic conditions, and offers a unique possibility to study the characteristic features of Arctic atmospheric trace constituents such as trace gases and aerosols.

The Zeppelin observatory is mostly unaffected by local sources and is considered to be within the boundary layer most of the time. On occasions when the top of the boundary layer is below the station altitude measurements can be considered to be representative of the lowermost free troposphere. The local wind pattern is dominated by east-southeast katabatic flow from Kongsvegen glacier (Beine et al., 2001). Orographic effects from surrounding hills may deviate local winds.

The observatory is owned by the Norwegian Polar Research Institute (NP), and the Norwegian Institute for Air Research (NILU) is responsible for the scientific program coordination. The Department of Applied Environmental Science, Unit for Atmospheric Science (ITM), Stockholm University, plays a key role in the monitoring of atmospheric aerosols and has performed observations of the high Arctic aerosol at Mt. Zeppelin since the year 2000. It is one of the longest observational series of aerosol number size distributions in polar environments. Alongside observations of the aerosol number size distribution, ITM further monitors the aerosol light absorption using a custom-built Particle Soot Absorption Photometer (PSAP) and an aerosol-scattering co- efficient using an integrating nephelometer TSI 3563. Total particle number concentrations larger than 3 and 10 nanometers are observed using TSI CPC model 3025 and TSI CPC model 3010, respectively. In this study, however, we will focus on the aerosol size distribution properties only.

The aerosol number size distribution is observed using a closed-loop Differential Mobility Particle Sizer (DMPS). During the period of operation, the system has undergone some changes with respect to inlet design and type of DMA used in the system. When the measurements started in the beginning of 2000, the system consisted of a CPC 3760 together with a short Hauke-type DMA (Jokinen and Makela, 1997; Knutson and Whitby, 1975). Initially, the observations covered the size distribution between 22 and $500 \mathrm{~nm}$. In October 2000, the size range of the instrument setup was adjusted to observe the size distribution between 20 and $630 \mathrm{~nm}$. This setup was used until the end of 2002, when the system was modernized and the short Hauke-type DMA was replaced by a medium size Hauke DMA. Both setups used the same TSI CPC 3760, and the size range observed remained the same. From 2005 the aerosol size distribution size range was further increased, covering particle sizes between 10 and $790 \mathrm{~nm}$. During end of 2005, the rain cover on the inlet was also replaced. The last change affecting the data dates to the end of 2008, when the sampling tubing was changed, leading to reduction of the diffusion losses in the sampling line. This in turn increased the detection efficiency of the smaller-sized particles.

Although the aim is to keep the measurement continuous, some gaps in the data set inevitably occurred due to measurement failure and other unforeseen events. Based on daily averaged aerosol size distributions the present data set covers $84 \%$ of the time from 2000 to 2010 (Fig. 1). During the period of measurements presented in this study there are no large gaps in the data apart from three longer periods of missing data (cf. Fig. 1; autumn-winter 2002, winter 2004 and winter 2008-2009). This may affect the representativeness of these years.

\section{Interannual variability of recorded data}

In order to assure consistency of the investigated data set a comparison of annually averaged number and volume distributions was performed. Figure 2 shows the 25-75th percentile range total number of aerosol number size distribution observations performed during the period of 2000-2010 (red surface) with overlaid annual median size distributions. It is evident that the annual median distributions of years 2000 and 2002 significantly differ from the rest. This is due to the fact that a large part of both these years is missing. For the year 2000 the observations did not start until the end of March, and large parts of the data for 2002 are missing due to the instrument temporarily being out of commission. Otherwise, the annual average distributions seem centered around the median of the whole measurement series. Figure 3 


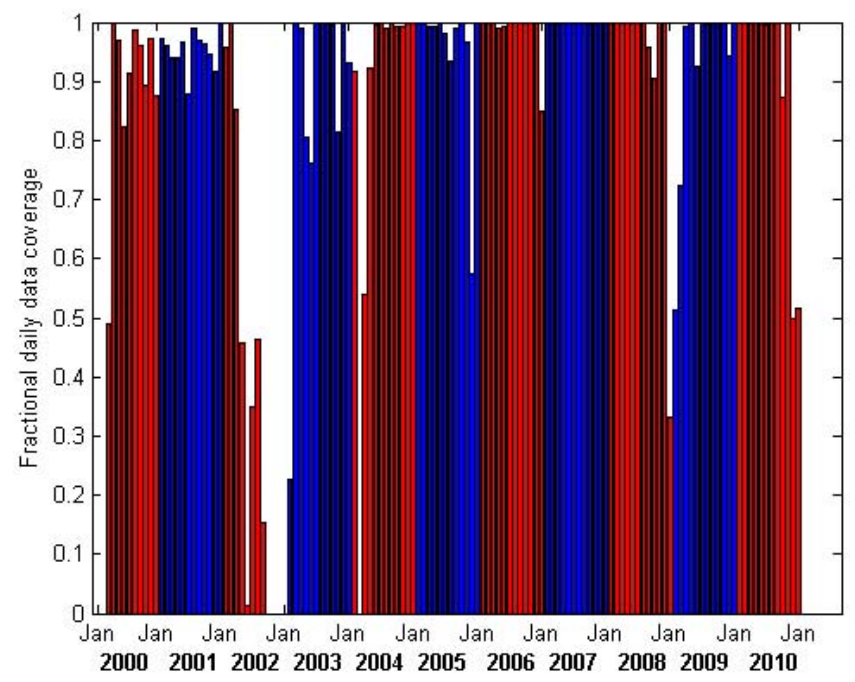

Fig. 1. Data coverage as fraction per month for the investigated period, March 2000-March 2010. Data are shown as percent of daily averages. Red bars correspond to even years, blue bars correspond to odd.

shows corresponding aerosol volume size distributions with upper and lower quartile range and annually averaged values. Apart from the obvious outliers corresponding to 2000 and 2002 previously described, there is a shift in the volume distribution towards larger sizes going from 2000-2010. Whether this is a result of changed instrument setup or actual change of the Arctic aerosol size distribution due to changes in transport pattern and sources and sinks is, however, uncertain. This deserves a more thorough analysis in future as it is not within the scope of the current study. Also note that the missing data periods during 2004 and 2008-2009 as a consequence render average size distributions calculated for these years less representative.

\subsection{Lognormal fitting procedure}

The data were fitted with three lognormal modes for the daily averaged data. Fitting was performed for size distribution data between 20 and $630 \mathrm{~nm}$ in order to assure that the analysis was performed on a data set with identical size range for the studied period. The modes roughly correspond to size ranges of the nuclei, Aitken and accumulation mode particles. The fit of 3215 daily average aerosol size distributions was performed based on the algorithm fmincon.m, available in Matlab Optimization toolbox.

\subsection{Trajectory calculations}

Throughout the studied period, hourly $240 \mathrm{~h}$ back trajectories were calculated using the HYSPLIT4 model (Draxler and Hess, 1998). Between 2000 and 2006 the trajectory calculations are based on meteorological data from the FNL data set, and from 2007 onwards they are based on the GDAS (Global

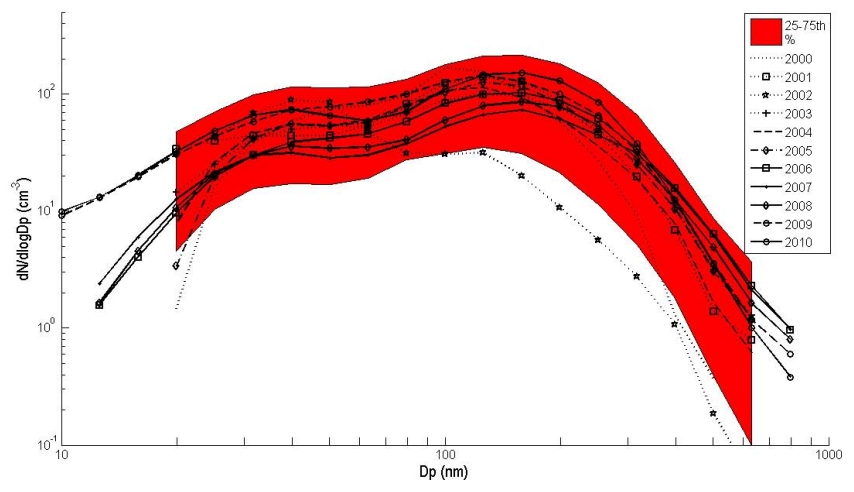

Fig. 2. Percentile range of aerosol number size distributions collected during 2000-2010 (red surface) and corresponding annual median aerosol number size distributions (black lines); pre-2006 data as dashed lines and post-2006 data as solid lines. Units in $\mathrm{dN} / \mathrm{d} \log D_{\mathrm{p}}, \mathrm{cm}^{-3}$.

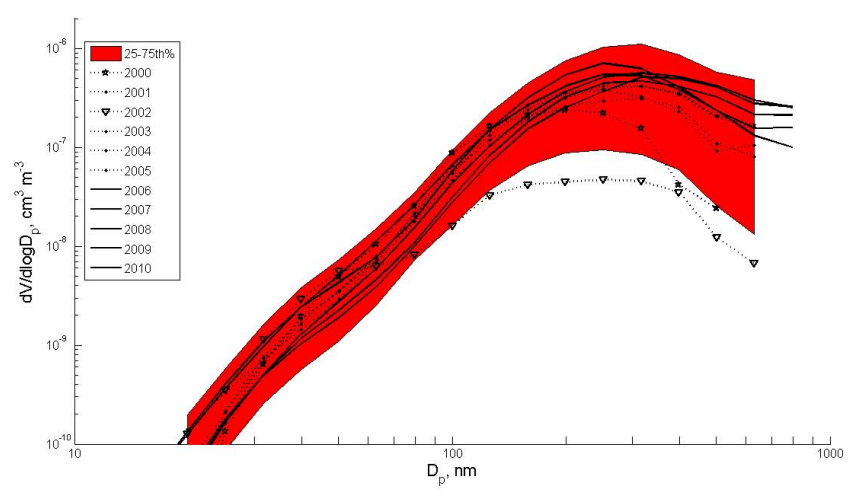

Fig. 3. Percentile range of aerosol volume size distributions collected during 2000-2010 (red surface) and corresponding annual median aerosol number size distributions (black lines); pre-2006 data as dashed lines and post-2006 data as solid lines. Units in $\mathrm{dV} / \mathrm{d} \log D_{\mathrm{p}}, \mathrm{cm}^{3} \mathrm{~m}^{-3}$.

Data Assimilation System) data set (cf. http://ready.arl.noaa. gov/archives.php). The trajectories will be used to estimate spatial distributions of the potential source areas that define the aerosol properties at Zeppelin. The same trajectories will further be used to study the air mass history in terms of precipitation intensity, which is supplied as optional hourly output along the calculated trajectories.

\section{Results and discussion}

The purpose of this study is to analyze long-term observations of the Arctic aerosol number size distributions towards a better understanding of what processes control Arctic aerosol properties.

First a survey of the general aerosol size distribution properties observed between the years 2000 and 2010 is presented. The second part will describe both seasonality of the 
aerosol properties and diurnal variability. The third part focuses on a study of air mass transport patterns using trajectory analysis and description of seasonal variability. Finally, the role of precipitation in shaping the aerosol size distribution in the Arctic environment will be analyzed and discussed (cf. Sect. 3.5).

\subsection{Average size distribution properties of the Arctic aerosol}

The Arctic aerosol concentration is generally very low, typically a couple of hundred particles per $\mathrm{cm}^{-3}$ (Strom et al., 2003). In addition, both integrated aerosol mass and surface concentrations are very low compared to observations performed in, e.g., the close-by boreal region of Scandinavia (Dal Maso et al., 2007). Figure 4 shows the median aerosol number, volume and surface size distribution for the studied period of March 2000-December 2010. The average number size distribution (Fig. 4a) is typically bimodal with one mode in Aitken (typically $D_{\mathrm{p}}<60 \mathrm{~nm}$ ) and one mode in accumulation mode size range (typically $D_{\mathrm{p}}>60 \mathrm{~nm}$ ). On average, the accumulation mode number concentration dominates the aerosol size distribution, and peaks around $150 \mathrm{~nm}$.

The aerosol surface distribution (Fig. 4b) is defined by roughly a single mode with the maximum peak located around $220 \mathrm{~nm}$.

The average volume size distribution (Fig. 4c) peaks at around $300 \mathrm{~nm}$. There is indication of a second mode in aerosol volume distribution, but its peak is located above the upper limit of the measurement range and extends towards a size of around $1 \mu \mathrm{m}$ or above.

Daily average aerosol number size distribution data have been fitted into three lognormal modes (cf. Sect. 2.2). In the following, we will use the terms nuclei, Aitken and accumulation modes for mode 1-3, respectively, although the mode 1 modal diameter is slightly too large to be called a nucleation mode. Nevertheless, this mode represents aerosol population in the smallest observed sizes, which potentially originate from new particle formation that occurred rather recently (an assumption based on the fact that the lifetime of the smallest observed particles is short, i.e. in the order of a couple of hours up to a day for a particle with $D_{\mathrm{p}}=10-20 \mathrm{~nm}$ ). The aerosol-number-size-distribution-fitted modal parameters are summarized in Table 1. During the ten years of measurements in this study, the smallest mode is typically centered around $25-40 \mathrm{~nm}$, and has a number concentration around 5$36 \mathrm{~cm}^{-3}$ as indicated by the $25-75$ th percentile range. These low values are indicative of only a small abundance of nuclei mode particles' annual basis. The second mode is typically located between 55 and $110 \mathrm{~nm}$, with a median modal concentration of $24 \mathrm{~cm}^{-3}$. The accumulation mode is the most dominating mode, with typical median concentration of 37 $\mathrm{cm}^{-3}$ and modal size between 130 and $190 \mathrm{~nm}$. As can be seen from the mean values in Table 1, episodically high particle concentrations in the different modes do occur, caus-
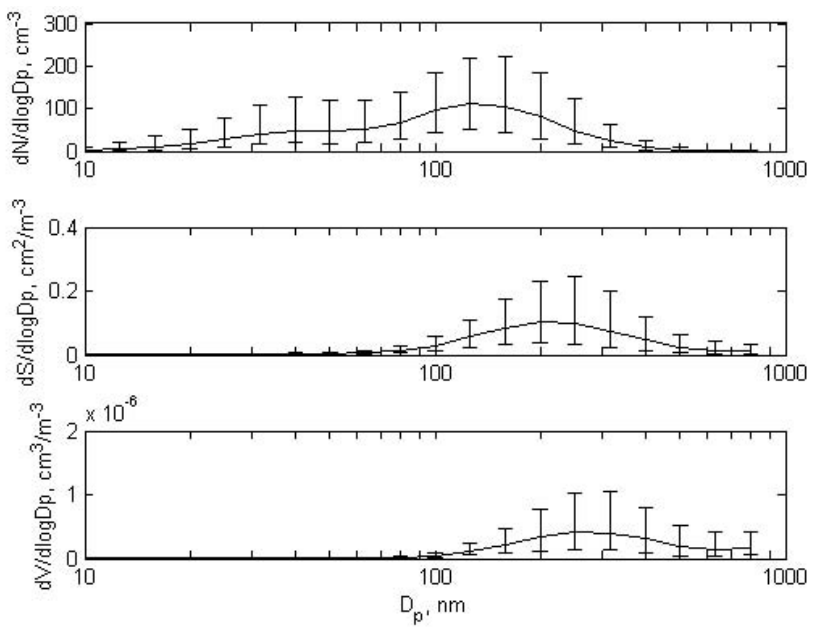

Fig. 4. Aerosol size distribution properties for the period of March 2000-March 2010 and 25-75th percentile ranges indicated. (a) Median aerosol number size distribution. Units in $\mathrm{cm}^{-3}$. (b) Median aerosol volume size distribution. Units in $\mathrm{cm}^{3} \mathrm{~m}^{-3}$. (c) Median aerosol surface distribution. Units in $\mathrm{cm}^{2} \mathrm{~m}^{-3}$.

ing a more than double mean values compared to the median. These events are likely caused by either new-particle formation events during summer (indicated by the comparably high concentration of nuclei mode particles) or episodes of long-range transport (in the case of high concentration of accumulation mode). The fact that the mean concentration of the nuclei mode is higher than the 75th percentile of the data suggests a small number of cases with comparably high nuclei mode number concentrations. This pattern can be linked to seasonal variability in aerosol size distribution, which will be discussed in following section.

\subsection{Strong seasonal variation of the aerosol size distribution properties}

Figure 5 shows seasonal variation of the monthly median and mean integral aerosol number concentration of submicron aerosol particles from $20 \mathrm{~nm}$ to $630 \mathrm{~nm}$ in diameter derived from number size distributions for the period of 2000-2010. Overall, the aerosol number density, typically in a range from 50 to $200 \mathrm{~cm}^{-3}$, is comparable to aerosol concentrations in coastal Antarctica (Koponen et al., 2003) and substantially lower than typical background aerosol concentrations in remote marine regions at lower latitudes where aerosol number concentration is usually between 300 and $500 \mathrm{~cm}^{-3}$ (Bates et al., 2000). The intra-annual trend in Fig. 5 indicates clear and repeating strong seasonality in aerosol number concentration. Minimum values are observed during autumn and the onset of winter $\left(\sim 50 \mathrm{~cm}^{-3}\right)$. Maximum concentrations are observed during the summer months, with a monthly mean of $250 \mathrm{~cm}^{-3}$ during July. Although the seasonal variation of the integral number concentration follows a pattern with maximum concentration of integral number during the summer 
Table 1. Median modal properties of the aerosol number size distribution as observed at Mt. Zeppelin, March 2000-March 2010. 25-75th percentile range within brackets, mean values within square brackets. Given are the median of modal number concentration $\left(N, \mathrm{~cm}^{-3}\right)$, modal geometrical standard deviation (GSD) and modal geometrical mean diameter $\left(D_{\mathrm{g}}, \mu \mathrm{m}\right)$.

\begin{tabular}{llll}
\hline & $N\left(\mathrm{~cm}^{-3}\right)$ & GSD & $D_{\mathrm{g}}(\mu \mathrm{m})$ \\
\hline Mode 1 & $13[40](5-36)$ & $1.43[1.55](1.29-1.69)$ & $0.0315[0.0311](0.0248-0.0386)$ \\
Mode 2 & $24[54](8-61)$ & $1.50[1.60](1.31-1.80)$ & $0.0841[0.084](0.0549-0.1120)$ \\
Mode 3 & $37[82](10-93)$ & $1.50[1.55](1.39-1.62)$ & $0.1555[0.177](0.1316-0.1895)$ \\
\hline
\end{tabular}

months, there are significant differences in the shape of the size distribution over the seasons, which are highlighted in Figs. 6 and 7. Figure 6 represents a spectral plot of the whole $10 \mathrm{yr}$ period averaged on a daily basis. The high concentrations during spring months of March-April are almost exclusively governed by the accumulation mode size aerosols, while the high summer concentrations are related to elevated number in the Aitken and nuclei mode size ranges. Thus, the aerosol size distribution during the haze period (i.e. the springtime) appears to be dynamically aged, and represents the terminal stage of the aerosol lifecycle (e.g. Tunved et al., 2004). The summer period aerosol size distribution is dominated by (most likely) freshly formed particles that have not yet undergone significant growth by condensation and coagulation and have not been affected by cloud processing and wet removal. From this perspective, the observations exhibit a strikingly sharp transition between spring and summer periods, representing a regime shift between polluted spring and the relatively cleaner summer. The springtime domination of accumulation mode particles is diminished in favor of smaller particles over the time period of a couple of days. This phenomenon has been studied in detail by Engvall et al. (2008b) using six years of aerosol size distribution observations from Mt. Zeppelin. It was shown that the sharp transition between these two extremes happens every year during the same period, within a couple of weeks, and cannot be explained by changes in air mass transport and source region influence alone. Instead, this transition is likely strongly linked to increased wet removal (e.g. Garrett et al., 2011) together with increased photochemical activity due to increased solar radiation. Wet removal and change of source areas reduce the condensation sink which allows for new particle formation to occur. This is of course dependent on a nucleating gas and its precursors, which could be either locally emitted, e.g. DMS from the ocean (Sharma et al., 2012), or, perhaps less likely, transported into the Arctic during certain transport conditions. Single particle analysis (Behrenfeldt et al., 2008) further indicates that samples taken before the rapid transition mainly consisted of spherical "organic-like" particles originating from Eurasia, while particles sampled after the transition are associated with an enhanced abundance of particles associated with both marine sources within the Arctic (e.g. sea salt) as well as continental sources including various organic constituents. Thus, while the spring maximum

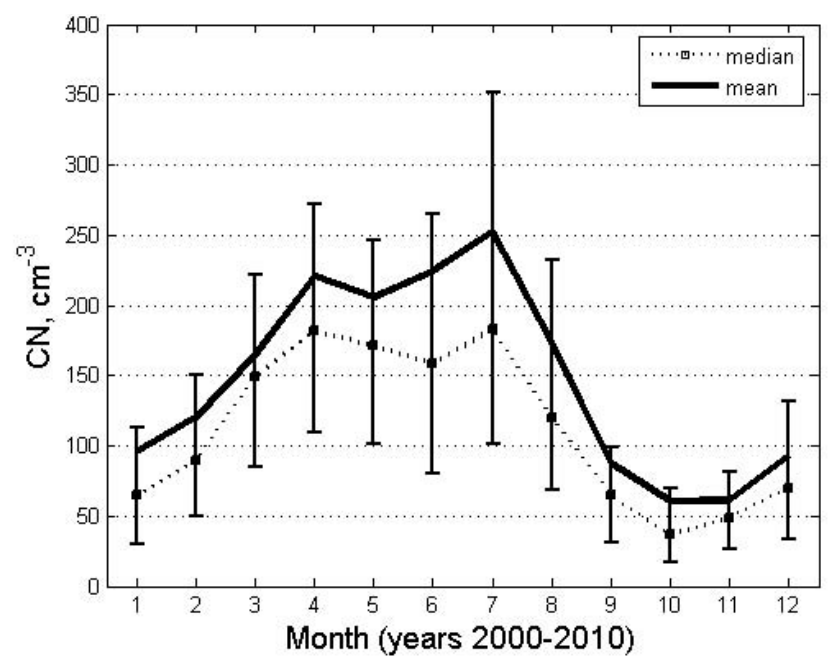

Fig. 5. Annual average variation of median and mean integrated number concentration per month March 2000-March 2010. 2575 th percentile ranges indicated by vertical "error bars".

(i.e. "the haze period") is linked to certain meteorological transport conditions, the high concentration of small particles during summer likely reflects local new particle formation within the Arctic domain. Another possibility that cannot be ruled out, however, is that these nuclei mode size particles are entrained from aloft.

Figure 7 further emphasizes the seasonal variability in terms of monthly average aerosol number size distributions for the studied time period: the Arctic haze period is dominated by an almost mono-modal accumulation mode aerosol, which shifts into a nuclei-Aitken-mode-size-rangedominated aerosol during the summer months. After the sun drops below the horizon during the end of the summer period, the size distributions again display more aged aerosol characteristics: the abundance of small particles decreases and the relative fraction of accumulation mode particles increases. This trend of decreasing total aerosol number density continues throughout September and October when the annual minimum in total aerosol number concentration is observed. From November the concentration of the accumulation mode aerosol slowly rises towards the next-year maximum during the following spring haze period. 


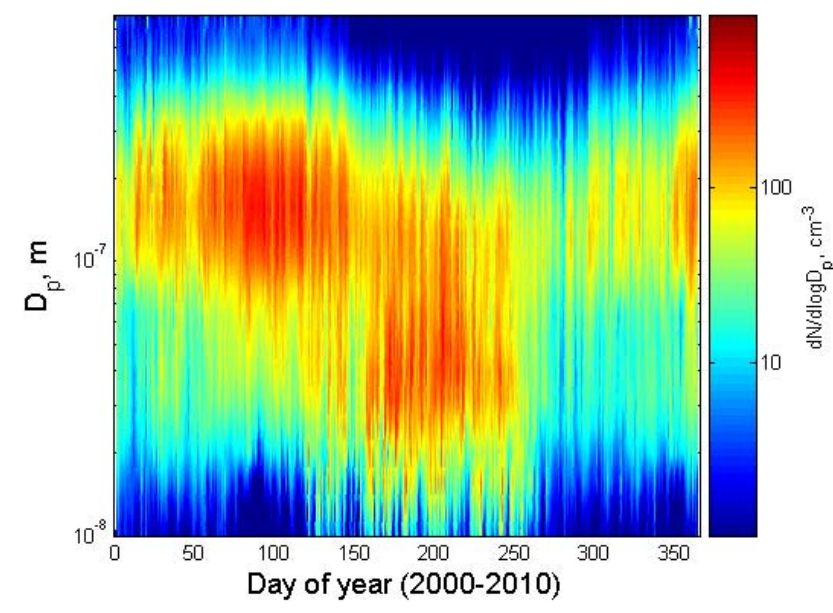

Fig. 6. Spectral plot of daily average aerosol number size distributions, March 2000-December 2010. Units on X-axis as day of year.
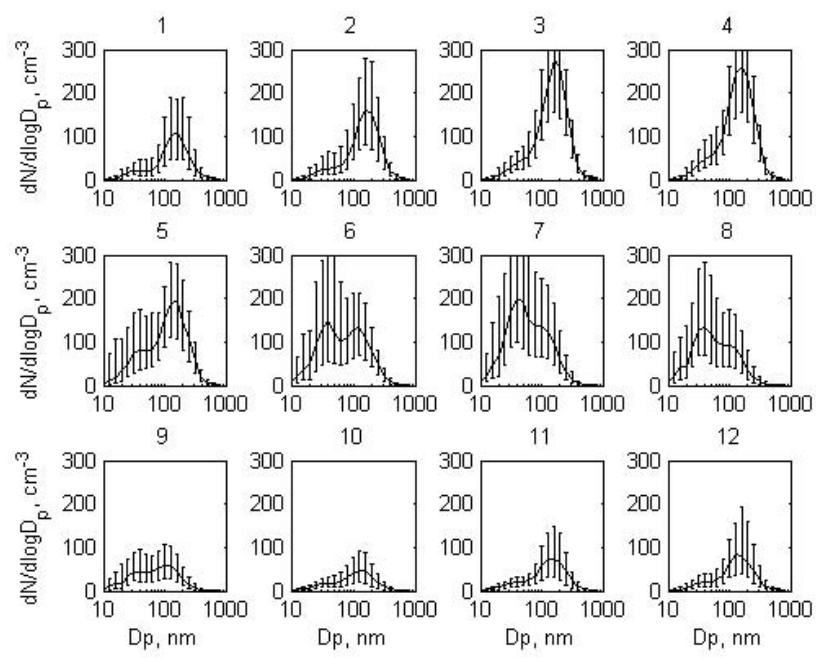

Fig. 7. Monthly median size distributions for the years of March 2000-March 2010. 25-75th percentile ranges indicated by errorbars. Corresponding lognormal-fitting parameters are shown in Table 2 .

Figure 7 is accompanied by Table A1 in Appendix A, providing monthly descriptive statistics for fitted aerosol number distributions. We will not address this table in detail, but do provide it for completeness as a reference for, e.g., model initialization and evaluation as well as for comparison with previously derived statistics from the Arctic environment.

Finally, Fig. 8 provides the seasonal variation of the integral mass $\left(\mu \mathrm{g} \mathrm{m}^{-3}\right)$ and surface $\left(\mathrm{cm}^{2} \mathrm{~m}^{-3}\right)$. The mass is calculated from the submicron aerosol number size distribution by simply assuming a density of $\rho=1 \mathrm{~g} \mathrm{~cm}^{-3}$ for ease of scaling (N.B. that dry aerosol densities are likely to be closer to $2 \mathrm{~g} \mathrm{~cm}^{-3}$ ). The winter months are, as previously mentioned, characterized by very low aerosol concentrations, with a dominance of accumulation mode size particles. Min-

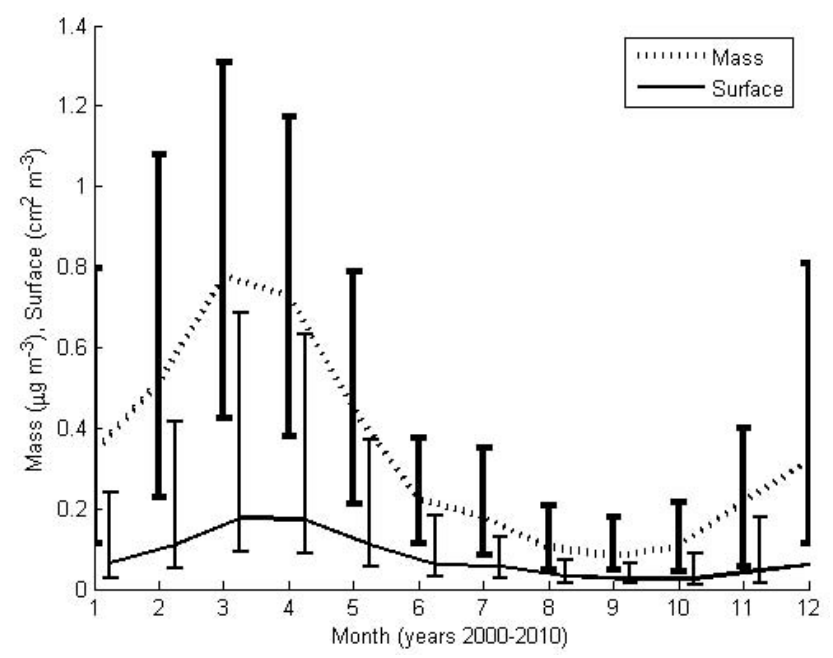

Fig. 8. Annual average variation of integrated surface and mass, March 2000-March 2010. Mass data calculated from aerosol number size distribution assuming a density of $\rho=1 \mathrm{~g} \mathrm{~cm}^{-3} .25-75$ th percentile ranges indicated by errorbars.

imum mass concentrations are observed during September, whereas the lowest number concentration was found in October. Not surprisingly, the mass concentration is largest during the Arctic haze period. Although relatively high for Arctic conditions, the maximum mass (around $0.8 \mu \mathrm{g} \mathrm{m}^{-3}$; or $1.6 \mu \mathrm{g} \mathrm{m}^{-3}$ assuming a density of $2 \mathrm{~g} \mathrm{~cm}^{-3}$ ) is small compared to continental sites (Van Dingenen et al., 2004). The annual variation of the integral surface concentration follows approximately the same pattern as the integral mass, but it is associated with a less-pronounced spring maximum.

In summary, the Arctic boundary layer aerosol seems to be predictable and repetitive with respect to the aerosol size distribution seasonality trends and properties. Typical phases of the observed aerosol number size distribution can be characterized by three significantly different regimes: (1) the summer period, with its dominance of sub- $60 \mathrm{~nm}$ particles, (2) the dark winter period with comparably few particles and dominance by accumulation mode size particles $(>60 \mathrm{~nm})$ slowly increasing in number, and (3) the Arctic haze period with highly elevated concentrations of accumulation mode aerosol and just a few nucleation and Aitken mode particles. The timing of the transition between different characteristic aerosol regimes is, based on this and previous studies (Engvall et al., 2008b; Bodhaine, 1989; Quinn et al., 2002), consistent and very well pronounced. 


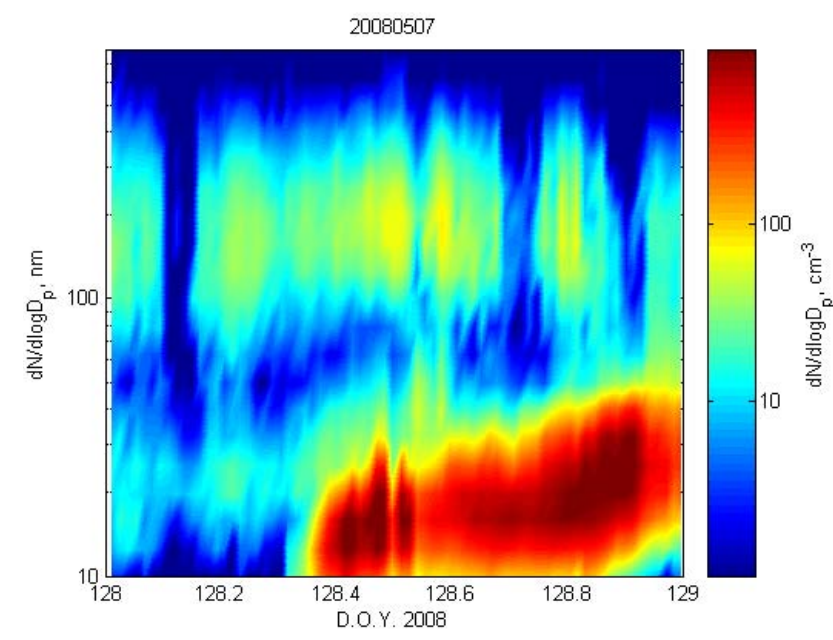

Fig. 9. Example of an Arctic nucleation event as observed 7 May 2008. $\mathrm{dN} / \mathrm{d} \log D_{\mathrm{p}}\left(\mathrm{cm}^{-3}\right)$ versus decimal day of year (D.O.Y.).

\subsection{New particle formation in the Arctic: diurnal characteristics of the Arctic aerosol number size distribution}

So far, we have focused on the seasonal properties and variation of the aerosol number size distribution. While the annual variability most likely reflects the large-scale features of Arctic meteorology and transport conditions, diurnal variability will reflect processes active on a much smaller temporal and spatial scale. One such phenomenon is new particle formation. New particle formation (e.g. Kulmala and Kerminen, 2008) is occasionally observed also in the Arctic environment. Figure 9 provides an example on how these events look when observed at the Zeppelin site. The newparticle formation events observed at Mt. Zeppelin exhibit several general features: (1) they occur during the sunlit period of the year (i.e. summer months of May-August), (2) they are detected around midday and (3) the newly formed particles seem to grow relatively slowly compared to other observations of new particle formation outside the Arctic. Many times, however, new particles are observed to appear, but without traceable growth. In this study we will not provide a detailed inventory of the nucleation events in terms of classification, growth rate and formation rate. Provision of similar analyses will be in future studies. Instead, we focus on more general diurnal trends of the Arctic number size distribution.

The data set including data from 2000-2010 was split into 12 monthly subsets, and these monthly subsets were further sorted according to time of day and then averaged, providing a monthly average diurnal variation for the studied decade. Firstly, when investigating median integral number concentrations there was no evident diurnal variability. From this we draw the conclusion that there is no typical systematic diurnal variation of either of the studied size classes on a
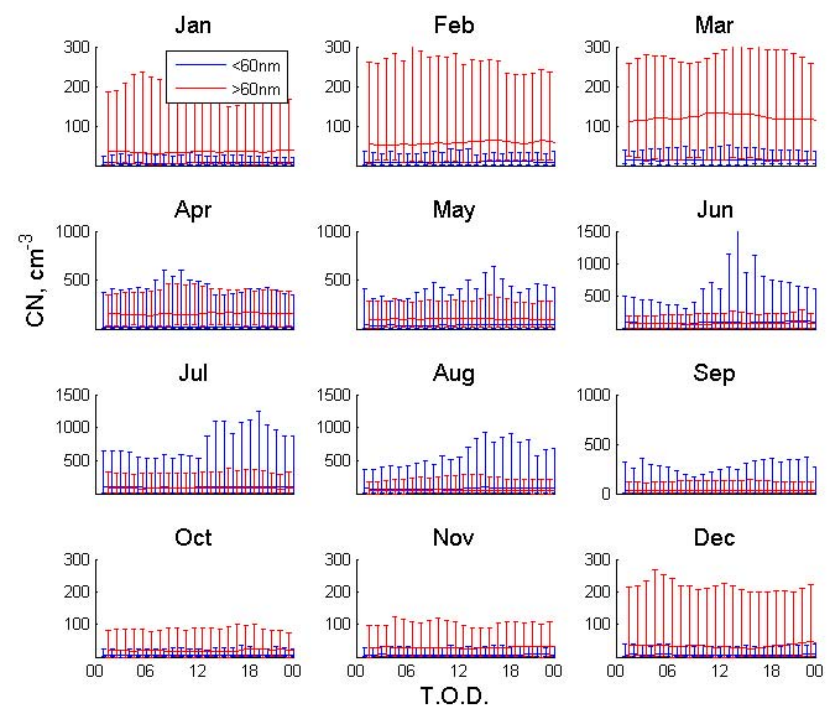

Fig. 10. Monthly (month 1-12) diurnal variation of median number concentration $D_{\mathrm{p}}<60 \mathrm{~nm}$ and $D_{\mathrm{p}}>60 \mathrm{~nm}$. 5-95th percentile ranges are indicated by errorbars. March 2000-March 2010. T.O.D. represents "Time of Day". Note the different scale of y-axis for the different months.

day-to-day basis. In order to highlight any diurnal variability that may be hidden in the data set, hourly 5 th and 95 th percentile ranges were calculated. This will reveal the more extreme cases in the data set and how these extremes in turn will vary on shorter time scales. Figure 10 shows monthly median and 5-95th percentile ranges of the $<60 \mathrm{~nm}$ and $>60 \mathrm{~nm}$ integral particle population. The selected cutoff of $60 \mathrm{~nm}$ is based on the average shape of the size distribution, consisting of a mode above $60 \mathrm{~nm}$ and mode below $60 \mathrm{~nm}$, with a typical Hoppel minimum (Hoppel and Frick, 1990) inbetween (cf. Fig. 4). This minimum is the result of in-cloud oxidation of especially sulphur dioxide that causes activated aerosol particles to accumulate sulphur and grow during cycling through non-precipitating clouds. Except for the period of June-September, when both the sub- $60 \mathrm{~nm}$ and the super$60 \mathrm{~nm}$ particle populations are of similar magnitude, median concentration of the sub- $60 \mathrm{~nm}$ population is always lower than the integral of the larger size classes.

There is only little or no diurnal variation observed for the larger particles. This suggests that the super- $60 \mathrm{~nm}$ accumulation mode aerosol particle number concentration is controlled by long-range transport, and it does not seem to be systematically affected by processes acting locally and on shorter time scales. The maximum concentration of sub$60 \mathrm{~nm}$ particle (as indicated by the 95th percentile) does seem to have a clear diurnal variability during Arctic summer, in particular June, July and August. The concentration of these particles increases around noon and starts to decrease again during the late afternoon. One plausible explanation for this would be vertical mixing with free tropospheric air reaching 
a maximum during midday, resulting in elevated particle concentration. This, however, would only be true if two conditions are fulfilled: firstly, the vertical gradient of super- $60 \mathrm{~nm}$ particles is small through the whole tropospheric column since no diurnal variability is identified for this size range. Secondly, particles are formed aloft. Concerning the first assumption, accumulation mode aerosol shows nearly homogeneous distribution through the Arctic troposphere (Engvall et al., 2008a) also including some, but not all, of the Arctic Haze occasions and plumes (Schmale et al., 2011). Regarding the location of particle formation, it is indicated by airborne measurements (Engvall et al., 2008a) that new particle formation in the free troposphere seem to be very rare in the Arctic. Instead, the shape of and continuity of the observed events (cf. Fig. 9) in many aspects resemble previously reported boundary layer nucleation events (Kulmala and Kerminen, 2008). The continuity (i.e. possibility to follow the evolution of the nuclei mode for several hours) further suggests that observed Arctic particle formation events are likely to take place simultaneously over large areas.

The data were further used to calculate monthly average diurnal variation in the full size distribution in order to reveal any systematic variation of the size distribution as a whole over a $24 \mathrm{~h}$ cycle (Fig. 11). During January-February the average day is characterized by a persistent accumulation mode and there is no evidence of any diurnal variation of the aerosol number size distribution. Entering March, the lack of diurnal variability continues, but as this is one of the more prominent haze months the number concentration of the accumulation mode is higher. All these months are as good as completely dark, although the sun rises towards the end of March. Entering April, the concentration of accumulation mode particles remains high and there seems to be an increased abundance of small $(<20 \mathrm{~nm})$ particles having a maximum concentration around noon. In May this picture is even more pronounced, and there seems to be on average a formation of small particles around noon which grow during the afternoon. In June, as previously described, the haze disappears, which means that the amount of accumulation mode particles is lower. During this month there is a persistent mode present in the Aitken size range and there is clear evidence of new particle formation starting to be visible around midday, followed by growth which is visible also during the following day. The sun is now high and the Arctic environment is characterized by constant daylight. This picture is preserved and enhanced during the following months of July-August, where the average data show typical signs of new particle formation and growth. Entering September, the sun sets and the signs of nucleation are diminished. This continues to be the case during the rest of the dark winter months, even though the amount of larger particles remains low.

We interpret this characteristic seasonal dependence as follows: during March-May, there is sunlight but also a large preexisting aerosol surface. Ice covers a large portion of
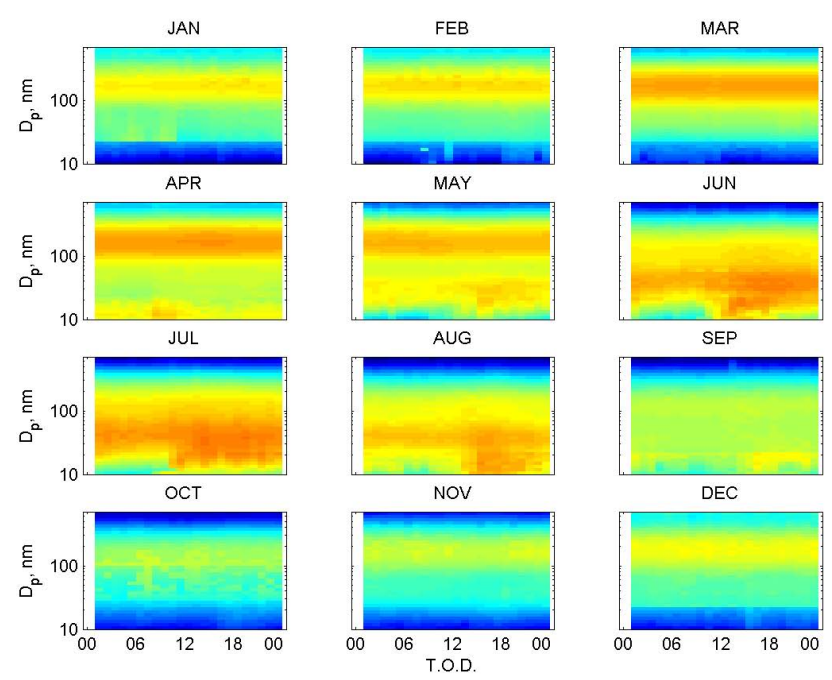

Fig. 11. Monthly diurnal variation of the mean of the aerosol number size distribution. T.O.D. represents "Time of Day".

the surrounding ocean. This results in poor conditions for new particle formation as newly formed particles are scavenged quickly, as are any potential nucleating gases, due to high condensation sink (which in any case are produced at a slow speed due to the lack of significant insolation). If the source of the precursor gases is the ocean itself, any emission of such is likely hindered by the ice cover. During June, conditions are quite different; more sunlight combined with less abundant preexisting accumulation mode particles means that the newly formed particles are able to grow into a large enough size range to allow for the particles to survive as individual entities until the next day. On average any diurnal variation in Aitken mode particles is therefore masked. This is a feature shared by the months of July and August as well. These months are all characterized by high insolation, low aerosol surface (and mass) and a much higher fraction of open ocean. In September, as days become shorter and solar radiation decreases, the particle production ceases and the period of dominating accumulation mode is reestablished. This again indicates the importance of photochemical production as the main driver for new particle formation in the Arctic environment.

The features associated with the diurnal characteristics of different size classes presented above support the idea that new particle formation in the Arctic boundary layer seems to be an important source of submicron particles during the polar summer. This corroborates earlier findings by, e.g., Strom et al. (2003, 2009) and Shaw (1989). The qualitative and quantitative behavior of the temporal evolution of small particles show a behavior consistent with new-particle formation events as observed at continental sites, and it is further indicative of the important balance between generation of nucleating and condensing vapors on the one hand and sink from making new particle material on the other hand 
(Kulmala and Kerminen, 2008). This picture also holds for the general features of nucleation events observed in the Arctic (i.e. detection of $10 \mathrm{~nm}$ particles around noon, which by assuming a growth rate of $2 \mathrm{~nm}$ per hour would have been formed some $5 \mathrm{~h}$ earlier), followed by growth that by its nature suggests condensational processes to be dominating (e.g. Dal Maso et al., 2005). Where exactly new particle formation takes place, what gaseous precursors are critical for aerosol nucleation and if these gaseous precursors dominantly are of natural or of anthropogenic origin remain to be addressed by future research.

\subsection{Strong seasonal variation of source areas: monthly transport climatology for the years 2000-2010}

It has been shown earlier that the Arctic aerosol size distribution properties and diurnal behavior exhibit strong seasonal variability. To a certain degree we have already discussed the role of meteorological parameters such as intensity of sunlight, balance between generation and consumption of condensable gases, growth and potential sources. However, we have not yet in detail discussed the role of the actual aerosol sources and source areas, and their seasonal variation. Arctic air mass source climatologies focusing mainly on the Arctic haze phenomenon are not something new, and detailed analysis regarding transport characteristics and source dependence may be found elsewhere (e.g. Hirdman et al., 2010; Polissar et al., 2001; Shaw, 1981). These and similar studies mainly address the source dependence of chemical composition and general meteorological characteristics. Here we will address source regions and transport patterns for air masses reaching Zeppelin station, by calculating relative horizontal source contribution based on trajectory calculations using the HYSPLIT model (cf. Sect. 2.3). We will investigate how different source areas potentially influence the aerosol observed at Mt. Zeppelin, and show how precipitation and associated wet removal shape the aerosol number size distribution and mass concentration during transport into the Arctic.

Figure 12a and $\mathrm{b}$ show the distribution of potential source areas experienced by a randomly selected trajectory during each month (January-June and July-December for Fig. 12a and $\mathrm{b}$, respectively) through the studied $10 \mathrm{yr}$ period. The map of potential source areas is constructed by summing up how many times a trajectory passed over the different grids, then dividing the number of passes per grid with the total number of trajectories investigated. Only the horizontal transport is considered, and we do not discriminate whether or not the trajectory is more or less close to the ground. This provides the likelihood of any given trajectory crossing a certain grid during the studied period of 2000 to 2010 . The procedure is repeated on a monthly basis. This results in a likelihood frequency that transport takes place from or over each one of the grids. The grid system itself is made up by $60 \times 60\left(1.5^{\circ}\right.$ Latitude and $6^{\circ}$ Longitude $)$ polar grids distributed around the receptor (Zeppelin). It is a well known fact that the accuracy of the trajectories deteriorate rapidly with increasing transport distance (Engstrom and Magnusson, 2009). For this application, i.e. when using a very large number of trajectories, we do, however, believe that a sufficient amount of information is retained by the individual trajectories to support the statistical analysis presented even when long transport time/distance is considered.

Starting with the Arctic haze period, there seems to be a strong probability of transport of air over the Arctic Ocean, and a majority of trajectories arrive within an approximately 120-degree sector extending to Alaska in the easterly direction and northern Siberia in the westerly direction (cf. Fig. 12a, frame 3-5 for March, April and May data). Transport from continental sources seems to be dominated by transport from Siberia, Eurasia and to some degree the European subcontinent. Only minor parts of the $240 \mathrm{~h}$ trajectories extend down to East Asia and Central Asia. Furthermore there is a minimum influence of air mass transport over the Atlantic Ocean. Entering June, this pattern starts to break up. The dominating transport sector defining the haze period is weakened and a much larger portion of air is funneled over the northern Atlantic Ocean.

During the following months of July-August this pattern gets even more pronounced, suggesting that the source areas experienced during the summer period are substantially different from those experienced during the haze. Data presented for the summer months of June-August (Fig. 12a and b) suggest that a majority of air mass transport goes along two separate branches: one southwest of Greenland and one branch arriving from the northwest, north of Greenland. During September the transport patterns shift once more, and for the period of October-December there is consistent transport through the Arctic from eastern Siberia to Alaska. Throughout January and February there is a strong shift westwards in source regions.

Thus, in simple terms, transport in terms of geographical origin is defined mainly by two different patterns: Atlantic air arriving from the southwest during the summer months and air mass transport over the Arctic Ocean from Siberia, Eurasia and partly Asia during the rest of the year. In terms of the summer period compared to the rest of the year, the transition between aerosol properties appear somewhat straightforward as the air mass transport patterns are significantly different between these two periods. We note that, although the transport patterns are similar for October and March, their respective aerosol characteristics are very different. Although not directly comparable with the current study, a recent study showed that northern parts of Eurasia are the dominating source regions of sulfate aerosols and equivalent black carbon in the Arctic (Hirdman et al., 2010). Hirdman et al. (2010) further show that large contributions from sources in Siberia and North America dominate during summertime. The importance of biomass burning in Russia, Siberia and Kazakhstan as a contribution to high springtime 

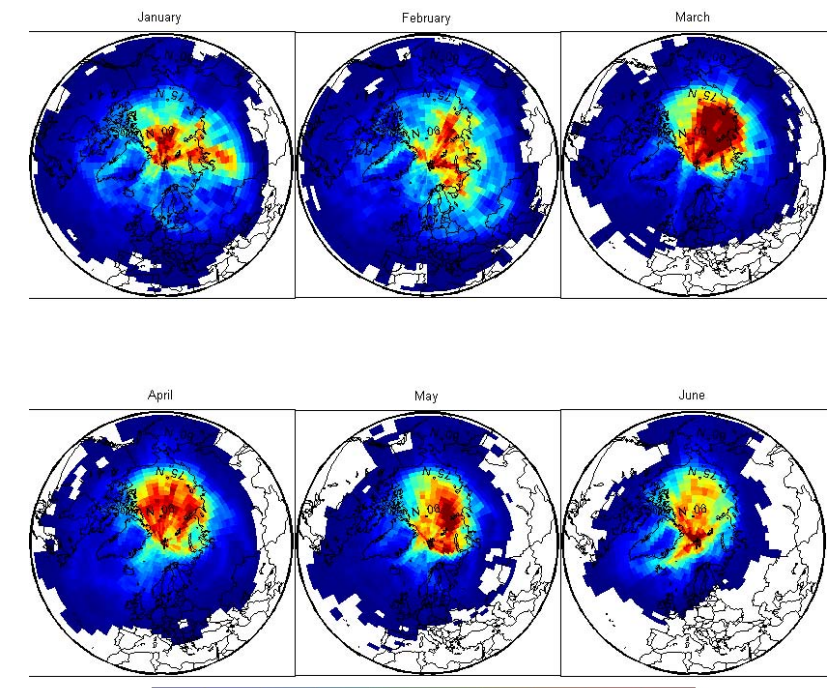

(a)
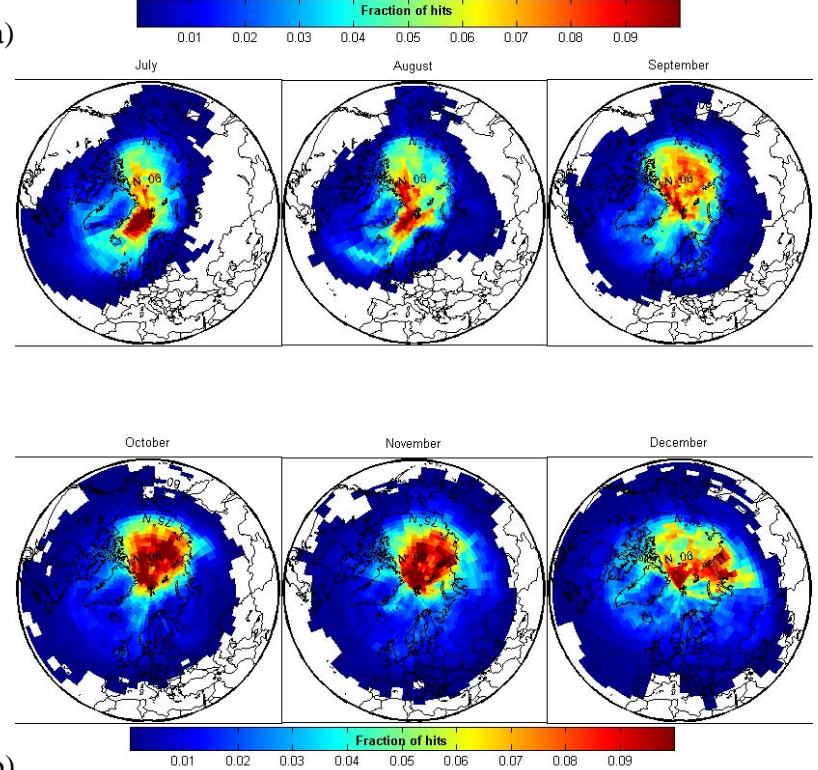

(b)

Fig. 12. Monthly relative source distribution of trajectories arriving at Mt. Zeppelin. Maps display the average possibility that any single trajectory has resided above a certain grid. This is calculated by dividing the number of times each grid has been passed by a trajectory and dividing this number by the total number of trajectories arriving at the receptor during that month. Data represent months January-June (a) and July-December (b), years 2000-2010.

aerosol loadings in the Arctic has previously been shown by Warneke et al. (2009).

In order to better understand how transport over different source regions may affect the aerosol properties in the Arctic, we also related the air mass transport to actual mass concentration observed at the receptor. These calculations are performed on a monthly basis for the whole period of 20002010. In simple terms, the mass concentration observed at Zeppelin during every hour is assigned to the grids crossed by the corresponding air mass trajectory. Performing this analysis for every trajectory and normalizing the result by the number of times a trajectory actually crossed any particular grid square provides a measure of how much mass on average is observed at the receptor (Zeppelin) after the trajectory has crossed any of the respective grids. The resulting plot is displayed in Fig. 13a (January-June) and 13b (July-December). The figure shows the mass concentration in $\mu \mathrm{g} \mathrm{m}^{-3}$ of integrated aerosol mass $\left(20-630 \mathrm{~nm}, \rho=1 \mathrm{~g} \mathrm{~cm}^{-3}\right)$ on average observed when a trajectory has crossed any particular grid.

Transport from central Europe and Russia (including Siberia) and northern parts of Asia provide the conditions for observation of relatively high mass concentration at the receptor of Mt. Zeppelin for all months. While this is true, it also becomes clear that the mass concentration assigned to these source regions varies substantially comparing the different months. For example, transport over eastern Siberia during March results in observed concentrations of about $0.4-0.5 \mu \mathrm{g} \mathrm{m}^{-3}$, while during September the same area results in observed relative mass concentrations in the range of $0.1 \mu \mathrm{g} \mathrm{m}^{-3}$. If we assume that the chosen approach at least to some degree represents the strength of the source areas, these results indicate either that the source strength changes substantially over the year or that the sinks during transport is significantly different when comparing the different months.

The submicron aerosol mass is almost exclusively governed by accumulation mode particles (Fig. 4). As described in Sect. 1, meteorological characteristics do play an important role in defining the seasonality of the Arctic aerosol. Furthermore, the most important sink for accumulation mode particles is wet removal (Buatmenard and Duce, 1986; Textor et al., 2006).

Thus, the average amount of precipitation experienced per month during the studied period was calculated. This was done by integrating precipitation intensity calculated by the HYSPLIT4 model along the trajectories and averaging the result per month for the studied period. The result is presented in Fig. 14 as monthly median amount of accumulated precipitation during the last 10 days $(240 \mathrm{~h})$. There is a strong annual variation in accumulated precipitation. Maximum values are estimated for the summer $\left(7-8 \mathrm{~mm}_{\text {tot }}\right.$ during July-September) months, and this amount gradually decreases during autumn, winter and spring to reach a minimum value during the haze period of March-May (2-3 mm tot during March-May). The fact that the minimum agrees well with the maximum in aerosol mass concentration suggests that precipitation does play a key role for abundance and annual variability of the observed Arctic aerosol properties. In the following section we will therefore adopt a statistical approach to investigate how precipitation and wet removal could contribute to shaping the Arctic aerosol size distribution properties. 

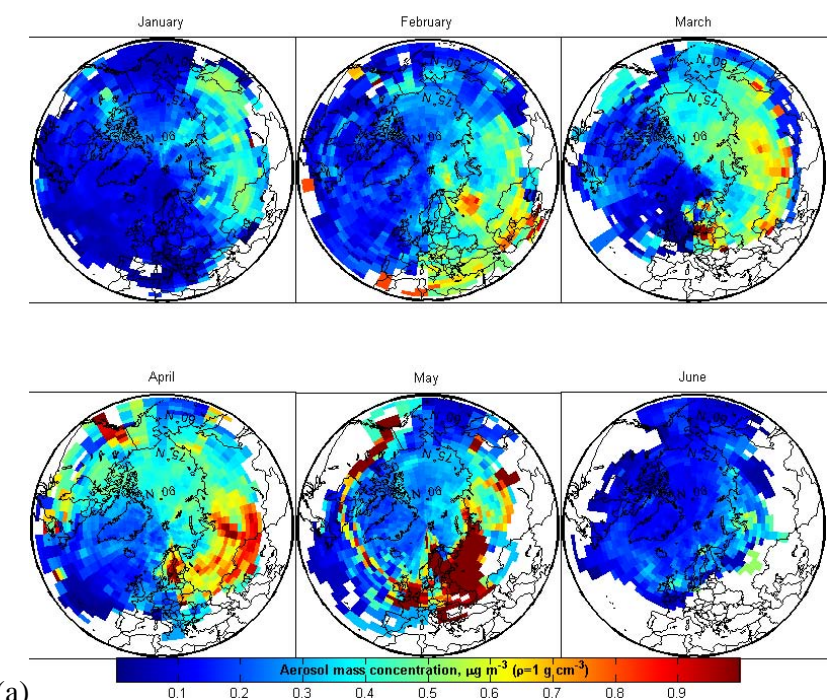

(a)
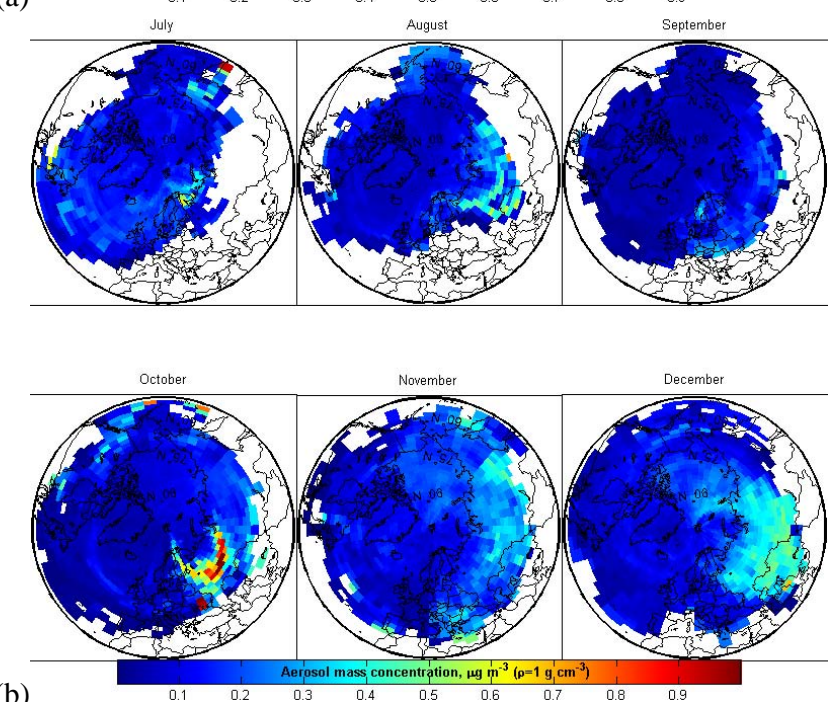

(b)

Fig. 13. Monthly maps showing the average concentration of submicron mass observed at Svalbard after crossing different source areas. Data represent months January-June (a) and July-December (b), years 2000-2010 (see text for details).

\subsection{Precipitation: both sink and source of Arctic aerosols?}

In order to resolve the potential importance of wet removal for shaping the Arctic aerosol, hourly values of precipitation intensity were extracted along each single trajectory and integrated during the full duration of transport for every trajectory. Integral precipitation during transport was compared to the observed mass concentration at the Zeppelin station. Subsequently, the integral precipitation was grouped according to amount of accumulated precipitation over the range of precipitation values using an increment of $0.5 \mathrm{~mm}$ per step. The corresponding mass was simultaneously calculated for every bin as 25 th, 50th and 75 th percentiles. The result is shown in Fig. 15.

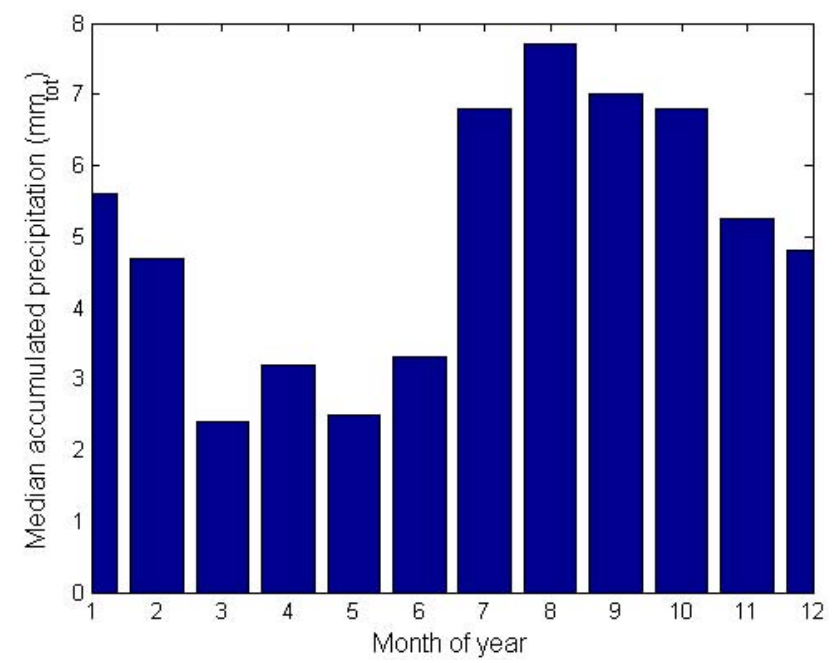

Fig. 14. Monthly median of accumulated precipitation experience by trajectories arriving at Svalbard during the period of 2000-2010.

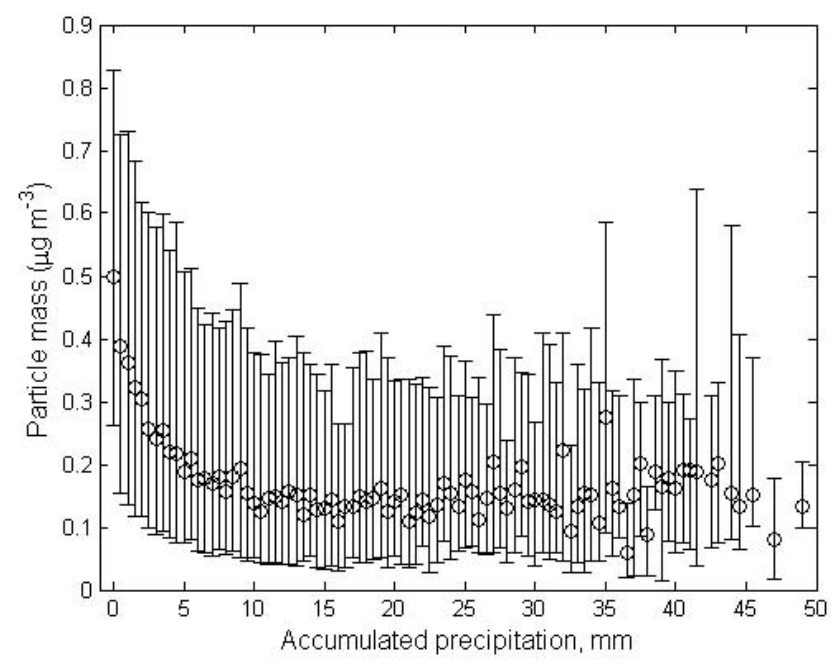

Fig. 15. Submicron aerosol mass evolution $(10-630 \mathrm{~nm} ; \rho=$ $1 \mathrm{~g} \mathrm{~cm}^{-3}$ ) as a function of accumulated precipitation along the trajectories. Data are shown as 25-75th percentile ranges per bin (solid lines) and median (circles). The figure includes all data collected between 2000 and 2010 .

It is seen that the mass versus precipitation follows an exponential function, with an initially rapid decrease in mass, followed by a decreased apparent removal rate when the accumulated precipitation is large and mass is small. At zero $\mathrm{mm}$ of accumulated precipitation, the typical mass concentration observed at zeppelin station is around $0.45 \mu \mathrm{g} \mathrm{m}^{-1}$ (covering a typical range of $0.18-0.62$ as indicated by the $25-$ 75 th percentile range). The mass concentration drops comparably fast up to about $10 \mathrm{~mm}$ of integral precipitation. When accumulated precipitation during the transport is larger than $10 \mathrm{~mm}$ decreases in aerosol mass with precipitation is less 


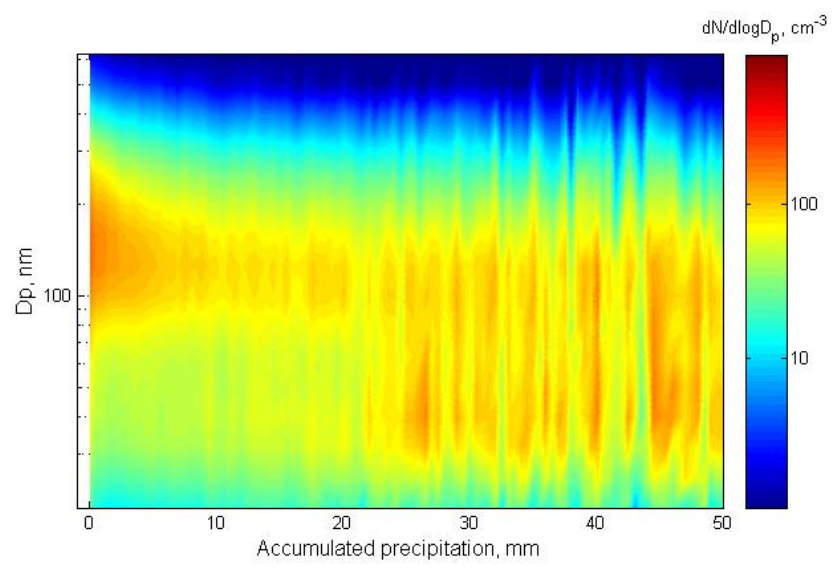

Fig. 16. Evolution of aerosol number size distribution as a function of accumulated precipitation $\left(\mathrm{mm}_{\mathrm{tot}}\right)$ along $240 \mathrm{~h}$ trajectories. Data are shown binned over a step size of $0.5 \mathrm{~mm}_{\text {tot }}$, and the corresponding size distributions over this ranges of precipitation is presented as median values.

obvious until there is no apparent change of aerosol mass with increasing precipitation.

In order to better resolve how precipitation influences the Arctic aerosol, a separate study was also performed to resolve how the wet removal affects the whole size distribution range and not only mass. Thus, in the same manner as for the mass, each hourly observed size distribution was associated with precipitation history during transport. The result was binned according to incremental accumulated precipitation $(0.5 \mathrm{~mm})$ during transport. The result is shown in Fig. 16 .

First of all, there is initially a rapid decrease of largersized particles. Assuming in-cloud scavenging to be the most important mechanism of removal, precipitation will remove the larger particles first and the removal will affect smaller and smaller particles as soon as the larger ones have been removed. This is at least conceptually sound considering the mechanisms and process active in activation scavenging (Guibert et al., 2003; Snider et al., 2003). The particles with the best ability to act will be consumed first; as the number and size of the accumulation mode decrease, smaller and smaller sizes become activated since there is less competition for the available supersaturation. Considering several consecutive precipitation events, the cloud droplets will be bigger and bigger for every cloud cycle if we assume the same dynamic forcing during the formation of the cloud (i.e. updraft, temperature, pressure and constant liquid water content (LWC)), and less particle number and mass will be removed per $\mathrm{mm}$ of rain as the size distribution is shifted towards smaller and fewer available CCNs. This mechanism is in qualitative agreement with the result presented in Fig. 15 and Fig. 16 (assuming that coalescence processes are the dominating mechanism of rain formation).

Secondly, after about $15-20 \mathrm{~mm}$ of total accumulated precipitation an apparent increase of nuclei and Aitken mode particles seem to take place. This could be a result of different meteorological conditions and transport conditions during occasions of high precipitation resulting in contributions from different source areas and/or different source strength (e.g. increase in wind speed may result in larger emissions of both DMS and sea salt particles) - that is, a mixture of conditions that result in the observed pattern. Another potential explanation is that the wet removal results in reduced mass and aerosol surface (i.e. reduced condensation sink), leading to higher concentration of gaseous precursors suitable for nucleation and new particle formation. This fits snugly with the previous discussion in Sect. 3.3 indicating a strong inverse relation between preexisting amount of aerosol surface and new particle formation. If the latter is true, the apparent increase of smaller-sized particles would be present only during the sunlit part of the year, since photochemistry is a prerequisite for formation of e.g. sulfuric acid in the gas phase.

Thus, the data were separated into two periods, one comprising data when the Arctic is dark (i.e. October-February), and one comprising data during the sunlit part of the year (i.e. March-September). The result is shown in Figs. 17 and 18 , respectively. It becomes clear that the apparent number increase of smaller-sized particles is much more pronounced during the summer months. It is also evident that this relative increase of small particles follows after an initial significant decrease of aerosols in the larger size classes (Fig. 17). When accumulation mode concentration is high (i.e. prior to substantial wet removal) the concentration of the finer fraction is very small and only increases after a large portion of the accumulation mode size particles has been removed. It is also evident that during the dark half of the year the apparent increase is missing, although there is a substantial reduction of accumulation mode particle concentration (Fig. 18), suggesting that the increase is dependent on the season, and thus possibly the rate of incoming solar radiation to support the photochemical reactions generating suitable precursor gases. Thus, wet removal paves the way for new particle formation via removal of larger-sized particles and thus condensation sink, allowing high enough concentrations of precursor gases to build up, supporting new particle formation. The rain would then act as a mechanism that facilitates a "shift of generation" with respect to the particle population. When the older bigger particles have been removed, a new aerosol starts to form, filling the gap created by the clouds and precipitation. It is also interesting to notice that these newly formed particles seem less accessible to removal by rain compared to the original, larger-sized aerosols, as the sensitivity to increasing precipitation is less for higher integral values of accumulated amount of precipitation $\left(\mathrm{mm}_{\mathrm{tot}}\right)$.

Consequently, it is suggested that clouds and rain and associated wet removal seem to be a key process in shaping the appearance of the Arctic aerosol. The effect of wet removal seem to be two-fold: it does not only include removal of larger size particles by scavenging; instead, by removing 


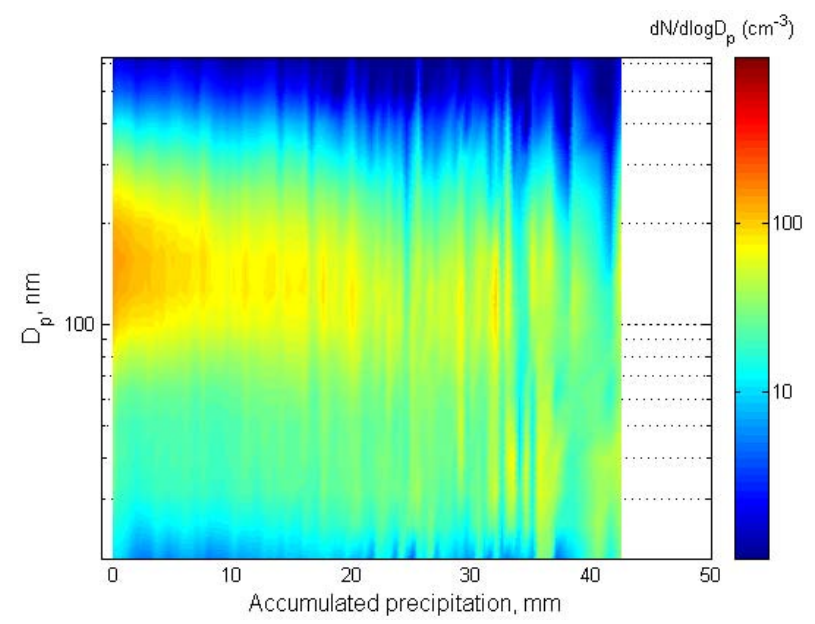

Fig. 17. Evolution of aerosol number size distribution as a function of accumulated precipitation $\left(\mathrm{mm}_{\mathrm{tot}}\right)$ along $240 \mathrm{~h}$ trajectories for the dark period (October-February). Data from 2000-2010.

the larger particles, rain events further establish conditions that favor new particle formation via nucleation.

Based on the findings presented in this study, a conceptually reasonable and qualitatively sound mechanistic explanation of the annual variation of aerosol properties may be proposed, whereby the key conditions to reach haze levels of particles include transport from areas with high emissions concurrent with sunlit transport conditions and low precipitation during transport.

\section{Summary and conclusions}

In this study we have presented a $10 \mathrm{yr}$ data set of aerosol size distribution measurements collected at the Zeppelin station located in Svalbard. We have investigated the data based on seasonality and diurnal variability and provide transport climatology for the studied period. We have presented statistics for the size distribution properties, including estimates of lognormal modal size distribution parameters on an annual and monthly basis.

We have shown that the aerosol mass, surface and size number distribution properties are a strong function of season, and that this seasonality is repeated from year to year. During the haze period in late winter and spring, the aerosol is dominated by accumulation mode size particles, and there seems to be an absence of contribution to particle number from local nucleation. The highest observed concentration of aerosol mass is observed when transport comes from Russia and central Europe. For all months except June-August, the dominating transport direction derived lies within an approximately 120-degree sector extending to Alaska in the easterly direction and northern Siberia in the westerly direction. Transport from land-based sources seems to be dominated by transport from Siberia, Eurasia and to some degree the

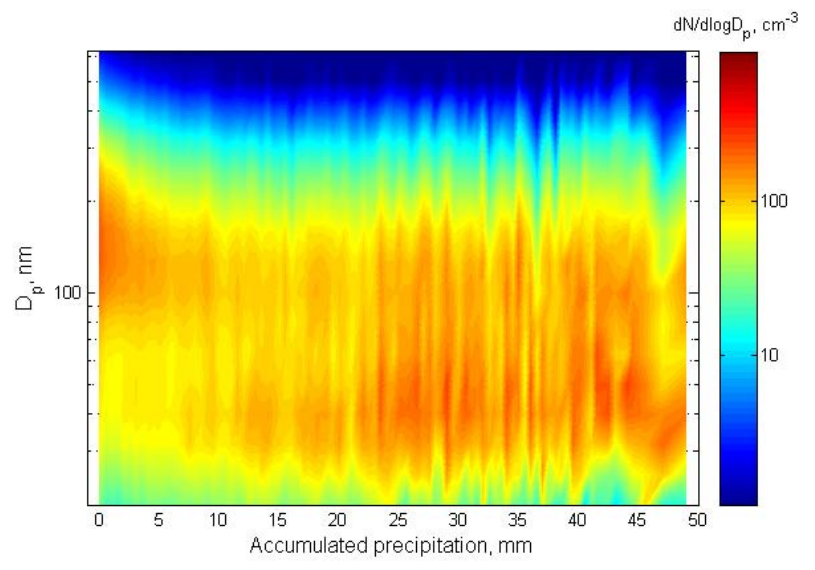

Fig. 18. Evolution of aerosol number size distribution as a function of accumulated precipitation ( $\mathrm{mm}_{\text {tot }}$ ) along $240 \mathrm{~h}$ trajectories for the sunlit period (March-September). Data from 2000-2010.

European subcontinent (which is in agreement with previous findings by Hirdman et al., 2010). Only a minor fraction of the $240 \mathrm{~h}$ trajectories extend down to East Asia and Central Asia. There is further a minimum influence of air mass transport over the Atlantic Ocean. During the summer months (June-August), a much larger fraction of air mass transport takes place over the Atlantic Ocean, and the summer season is characterized by higher fraction of smaller-sized particles, which is suggested to have been formed locally.

We further show that transport from dominating source regions into the Arctic during the haze periods is characterized by low amounts of precipitation (on average $2-3 \mathrm{~mm}$ of rain during the last 10 days), and that summertime is associated with the highest amount of precipitation (on average $7-8 \mathrm{~mm}$ of rain during last 10 days). By investigating the relation between aerosol mass and calculated precipitation we demonstrate a strong link between observed mass and precipitation history, suggesting that wet removal largely control the properties of the aerosol size distribution observed in Svalbard. This is further supported by an analogous analysis of the size distribution properties and their relation to experienced amount of precipitation. During the winter period, wet removal gradually diminishes the accumulation mode particles, and this decrease is most rapid when the amount of accumulated precipitation is comparably small. Performing the same analysis for the summer months demonstrates that, although precipitation initially removes aerosol mass and number, wet removal also seems to facilitate conditions that favor new particle formation and growth. This was demonstrated as a gradual increase in nuclei-Aitken mode size particles as the amount of precipitation increased further during the summer months. The fact that this was only observed during summer suggests that photochemistry plays a central role in formation of these small particles and that this formation of new particles only takes place when the balance between generation and removal of nucleating gases is favorable (i.e. source 
Table A1. Modal parameters and their corresponding 25-75th percentile ranges for the period of March 2000-December 2010. The lognormal fitting is based on daily average data for the selected time period. Given are the median of modal number concentration $\left(N, \mathrm{~cm}^{-3}\right)$, modal geometrical standard deviation (GSD) and modal geometrical mean diameter $\left(D_{\mathrm{g}}, \mu \mathrm{m}\right)$ for modes 1-3.

\begin{tabular}{|c|c|c|c|c|c|c|c|c|c|}
\hline & $\begin{array}{l}N_{1} \\
\left(\mathrm{~cm}^{-3}\right)\end{array}$ & GSD 1 & $\begin{array}{l}D_{g, 1} \\
(\mu \mathrm{m})\end{array}$ & $N_{2}\left(\mathrm{~cm}^{3}\right)$ & $\mathrm{GSD}_{2}$ & $\begin{array}{l}D_{g, 2} \\
(\mu \mathrm{m})\end{array}$ & $\begin{array}{l}N_{3} \\
\left(\mathrm{~cm}^{-3}\right)\end{array}$ & $\mathrm{GSD}_{3}$ & $\begin{array}{l}D_{g, 3} \\
(\mu \mathrm{m})\end{array}$ \\
\hline Jan & $\begin{array}{l}9 \\
(4-17)\end{array}$ & $\begin{array}{l}1.54 \\
(1.36-1.83)\end{array}$ & $\begin{array}{l}0.0319 \\
(0.024-0.04)\end{array}$ & $\begin{array}{l}13 \\
(3-26)\end{array}$ & $\begin{array}{l}1.42 \\
(1.22-1.83)\end{array}$ & $\begin{array}{l}0.1043 \\
(0.069-0.122)\end{array}$ & $\begin{array}{l}40 \\
(16-82)\end{array}$ & $\begin{array}{l}1.45 \\
(1.37-1.61)\end{array}$ & $\begin{array}{l}0.177 \\
(0.15-0.224)\end{array}$ \\
\hline Feb & $\begin{array}{l}10 \\
(4-28)\end{array}$ & $\begin{array}{l}1.57 \\
(1.38-1.85)\end{array}$ & $\begin{array}{l}0.0312 \\
(0.024-0.039)\end{array}$ & $\begin{array}{l}25 \\
(9-55)\end{array}$ & $\begin{array}{l}1.49 \\
(1.28-1.79)\end{array}$ & $\begin{array}{l}0.1095 \\
(0.081-0.13)\end{array}$ & $\begin{array}{l}53 \\
(23-102)\end{array}$ & $\begin{array}{l}1.44 \\
(1.36-1.56)\end{array}$ & $\begin{array}{l}0.1851 \\
(0.16-0.227)\end{array}$ \\
\hline Mar & $\begin{array}{l}10 \\
(5-21)\end{array}$ & $\begin{array}{l}1.44 \\
(1.31-1.67)\end{array}$ & $\begin{array}{l}0.0365 \\
(0.029-0.04)\end{array}$ & $\begin{array}{l}26 \\
(9-55)\end{array}$ & $\begin{array}{l}1.58 \\
(1.28-1.91)\end{array}$ & $\begin{array}{l}0.0977 \\
(0.066-0.124)\end{array}$ & $\begin{array}{l}102 \\
(41-172)\end{array}$ & $\begin{array}{l}1.48 \\
(1.41-1.57)\end{array}$ & $\begin{array}{l}0.1712 \\
(0.149-0.198)\end{array}$ \\
\hline Apr & $\begin{array}{l}13 \\
(6-29)\end{array}$ & $\begin{array}{l}1.4 \\
(1.3-1.59)\end{array}$ & $\begin{array}{l}0.0359 \\
(0.028-0.04)\end{array}$ & $\begin{array}{l}26 \\
(9-67)\end{array}$ & $\begin{array}{l}1.61 \\
(1.29-1.9)\end{array}$ & $\begin{array}{l}0.0962 \\
(0.06-0.128)\end{array}$ & $\begin{array}{l}119 \\
(54-188)\end{array}$ & $\begin{array}{l}1.51 \\
(1.45-1.58)\end{array}$ & $\begin{array}{l}0.1632 \\
(0.148-0.186)\end{array}$ \\
\hline May & $\begin{array}{l}21 \\
(6-54)\end{array}$ & $\begin{array}{l}1.37 \\
(1.26-1.54)\end{array}$ & $\begin{array}{l}0.0316 \\
(0.025-0.039)\end{array}$ & $\begin{array}{l}32 \\
(11-67)\end{array}$ & $\begin{array}{l}1.55 \\
(1.3-1.89)\end{array}$ & $\begin{array}{l}0.0682 \\
(0.048-0.114)\end{array}$ & $\begin{array}{l}75 \\
(32-125)\end{array}$ & $\begin{array}{l}1.57 \\
(1.49-1.63)\end{array}$ & $\begin{array}{l}0.1558 \\
(0.139-0.178)\end{array}$ \\
\hline Jun & $\begin{array}{l}36 \\
(10-92)\end{array}$ & $\begin{array}{l}1.36 \\
(1.25-1.57)\end{array}$ & $\begin{array}{l}0.0297 \\
(0.025-0.035)\end{array}$ & $\begin{array}{l}44 \\
(16-101)\end{array}$ & $\begin{array}{l}1.49 \\
(1.36-1.74)\end{array}$ & $\begin{array}{l}0.0619 \\
(0.048-0.091)\end{array}$ & $\begin{array}{l}34 \\
(11-80)\end{array}$ & $\begin{array}{l}1.53 \\
(1.4-1.63)\end{array}$ & $\begin{array}{l}0.1407 \\
(0.13-0.168)\end{array}$ \\
\hline Jul & $\begin{array}{l}40 \\
(11-111)\end{array}$ & $\begin{array}{l}1.44 \\
(1.27-1.79)\end{array}$ & $\begin{array}{l}0.0308 \\
(0.024-0.037)\end{array}$ & $\begin{array}{l}64 \\
(25-135)\end{array}$ & $\begin{array}{l}1.49 \\
(1.35-1.71)\end{array}$ & $\begin{array}{l}0.0558 \\
(0.048-0.076)\end{array}$ & $\begin{array}{l}31 \\
(7-77)\end{array}$ & $\begin{array}{l}1.5 \\
(1.39-1.6)\end{array}$ & $\begin{array}{l}0.1312 \\
(0.13-0.158)\end{array}$ \\
\hline Aug & $\begin{array}{l}34 \\
(9-71)\end{array}$ & $\begin{array}{l}1.38 \\
(1.26-1.66)\end{array}$ & $\begin{array}{l}0.0306 \\
(0.025-0.036)\end{array}$ & $\begin{array}{l}45 \\
(18-99)\end{array}$ & $\begin{array}{l}1.48 \\
(1.36-1.67)\end{array}$ & $\begin{array}{l}0.0606 \\
(0.046-0.085)\end{array}$ & $\begin{array}{l}16 \\
(3-49)\end{array}$ & $\begin{array}{l}1.47 \\
(1.36-1.61)\end{array}$ & $\begin{array}{l}0.13 \\
(0.13-0.152)\end{array}$ \\
\hline Sep & $\begin{array}{l}14 \\
(4-30)\end{array}$ & $\begin{array}{l}1.34 \\
(1.27-1.54)\end{array}$ & $\begin{array}{l}0.0291 \\
(0.023-0.036)\end{array}$ & $\begin{array}{l}24 \\
(8-47)\end{array}$ & $\begin{array}{l}1.53 \\
(1.41-1.76)\end{array}$ & $\begin{array}{l}0.0812 \\
(0.055-0.101)\end{array}$ & $\begin{array}{l}9 \\
(2-25)\end{array}$ & $\begin{array}{l}1.49 \\
(1.32-1.65)\end{array}$ & $\begin{array}{l}0.1409 \\
(0.13-0.186)\end{array}$ \\
\hline Oct & $\begin{array}{l}6 \\
(2-11)\end{array}$ & $\begin{array}{l}1.48 \\
(1.34-1.75)\end{array}$ & $\begin{array}{l}0.0296 \\
(0.024-0.037)\end{array}$ & $\begin{array}{l}10 \\
(4-26)\end{array}$ & $\begin{array}{l}1.53 \\
(1.37-1.84)\end{array}$ & $\begin{array}{l}0.0953 \\
(0.072-0.112)\end{array}$ & $\begin{array}{l}12 \\
(2-33)\end{array}$ & $\begin{array}{l}1.53 \\
(1.42-1.66)\end{array}$ & $\begin{array}{l}0.1495 \\
(0.13-0.183)\end{array}$ \\
\hline Nov & $\begin{array}{l}7 \\
(4-12)\end{array}$ & $\begin{array}{l}1.48 \\
(1.35-1.65)\end{array}$ & $\begin{array}{l}0.0316 \\
(0.027-0.038)\end{array}$ & $\begin{array}{l}9 \\
(4-22)\end{array}$ & $\begin{array}{l}1.51 \\
(1.3-1.89)\end{array}$ & $\begin{array}{l}0.0972 \\
(0.067-0.117)\end{array}$ & $\begin{array}{l}26 \\
(6-47)\end{array}$ & $\begin{array}{l}1.5 \\
(1.39-1.62)\end{array}$ & $\begin{array}{l}0.1612 \\
(0.141-0.198)\end{array}$ \\
\hline Dec & $\begin{array}{l}10 \\
(4-22)\end{array}$ & $\begin{array}{l}1.6 \\
(1.41-1.95)\end{array}$ & $\begin{array}{l}0.0299 \\
(0.023-0.037)\end{array}$ & $\begin{array}{l}12 \\
(4-25)\end{array}$ & $\begin{array}{l}1.38 \\
(1.25-1.79)\end{array}$ & $\begin{array}{l}0.1017 \\
(0.068-0.126)\end{array}$ & $\begin{array}{l}36 \\
(16-91)\end{array}$ & $\begin{array}{l}1.5 \\
(1.4-1.68)\end{array}$ & $\begin{array}{l}0.1707 \\
(0.144-0.203)\end{array}$ \\
\hline
\end{tabular}

of precursor gases, photochemical activity and low condensation sink)

Based on the findings, we can, at least qualitatively, describe the Arctic aerosol year based on the characteristics of land-based sources, sinks (mainly wet deposition) en route to Svalbard, and photochemical activity. Thus, during the haze period, precipitation and wet removal is at a minimum, which results in effective transport of pollutants into the Arctic. Although the haze period is partly sunlit, the sink constituted by the large concentration of preexisting aerosols hinders nucleation and growth. When entering the summer, the source areas are shifted and the amount of precipitation increases, which results in low mass and surface concentration. This low concentration of large-sized particles and maximum photochemical activity leads to new particle formation, and the aerosol is dominated by a comparably large amount of small particles. During the end of the summer the intensity of sunlight decreases and, despite low concentration of large particles, new particle formation comes to a halt as the production of nucleating vapors is too slow. This state progresses during the rest of the year (October-February). The trajectories experience less and less precipitation during transport, which is reflected by increasing aerosol mass concentration. The combined effect of sources and sinks in terms of wet removal brings about a new haze event the following year, and the cycle is repeated. In summary, precipitation seems to be a major factor, not only acting as a direct sink of particles; wet removal also provides the mechanism that allows for a generation shift of the aerosol population. Situations with substantial wet removal provide a low enough condensation sink to allow for formation of new particle number to be formed via new-particle formation events as long as there is sufficient photochemistry going on.

Although this mechanistic explanation seems to agree with the results presented in this study, a number of other mechanisms may play important roles. To a certain extent, our findings corroborate earlier mechanistic implications presented by, e.g., Shaw (1981) and Quinn et al. (2007), especially regarding the characteristic transport conditions and absence of significant wet removal during the Arctic haze period.

Acknowledgements. Funding for this study was provided through the Swedish Environmental Protection Agency (Naturvårdsverket, $\mathrm{NV}$ ) as part of the environmental monitoring program and from the Swedish Research Council (Vetenskapsrådet, VR) within the framework of CLIMSLIP (CLimate IMpacts of Short-Lived Pollutants in the polar region). The efforts made by Daniel Partridge in improving the language are greatly acknowledged, as are the valuable comments and suggestions made by two anonymous referees. The authors acknowledge Tabea Hennig and Birgitta Noone for their work with maintenance of the measurement equipment used in this study.

Edited by: M. Krämer 


\section{References}

Albrecht, B. A.: Aerosols, cloud microphysics and fractional cloudiness, Science, 245, 1227-1230, doi:10.1126/science.245.4923.1227, 1989.

Bates, T. S., Quinn, P. K., Covert, D. S., Coffman, D. J., Johnson, J. E., and Wiedensohler, A.: Aerosol physical properties and processes in the lower marine boundary layer: a comparison of shipboard sub-micron data from ACE-1 and ACE-2, Tellus B, 52, 258-272, doi:10.1034/j.1600-0889.2000.00021.x, 2000.

Behrenfeldt, U., Krejci, R., Strom, J., and Stohl, A.: Chemical properties of Arctic aerosol particles collected at the Zeppelin station during the aerosol transition period in May and June of 2004, Tellus B, 60, 405-415, doi:10.1111/j.1600-0889.2008.00349.x, 2008.

Beine, H. J., Argentini, S., Maurizi, A., Mastrantonio, G., and Viola, A.: The local wind field at Ny-Alesund and the Zeppelin mountain at Svalbard, Meteorol. Atmos. Phys., 78, 107-113, 2001.

Bodhaine, B. A.: Barrow surface aerosol - 1976-1986, Atmos. Environ., 23, 2357-2369, doi:10.1016/0004-6981(89)90249-7, 1989.

Brock, C. A., Cozic, J., Bahreini, R., Froyd, K. D., Middlebrook, A. M., McComiskey, A., Brioude, J., Cooper, O. R., Stohl, A., Aikin, K. C., de Gouw, J. A., Fahey, D. W., Ferrare, R. A., Gao, R.-S., Gore, W., Holloway, J. S., Hübler, G., Jefferson, A., Lack, D. A., Lance, S., Moore, R. H., Murphy, D. M., Nenes, A., Novelli, P. C., Nowak, J. B., Ogren, J. A., Peischl, J., Pierce, R. B., Pilewskie, P., Quinn, P. K., Ryerson, T. B., Schmidt, K. S., Schwarz, J. P., Sodemann, H., Spackman, J. R., Stark, H., Thomson, D. S., Thornberry, T., Veres, P., Watts, L. A., Warneke, C., and Wollny, A. G.: Characteristics, sources, and transport of aerosols measured in spring 2008 during the aerosol, radiation, and cloud processes affecting Arctic Climate (ARCPAC) Project, Atmos. Chem. Phys., 11, 2423-2453, doi:10.5194/acp-11-24232011, 2011.

Buatmenard, P. and Duce, R. A.: Precipitation Scavenging of Aerosol-Particles over Remote Marine Regions, Nature, 321, 508-510, 1986.

Charlson, R. J., Schwartz, S. E., Hales, J. M., Cess, R. D., Coakley, J. A., Hansen, J. E., and Hofmann, D. J.: Climate forcing by anthropogenic aerosols, Science, 255, 423-430, doi:10.1126/science.255.5043.423, 1992.

Clarke, A. D. and Noone, K. J.: Soot in the Arctic snowpack-a cause for perturbation in radiative transfer, Atmos. Environ., 19, 20452053, doi:10.1016/0004-6981(85)90113-1, 1985.

Dal Maso, M., Kulmala, M., Riipinen, I., Wagner, R., Hussein, T., Aalto, P. P., and Lehtinen, K. E. J.: Formation and growth of fresh atmospheric aerosols: eight years of aerosol size distribution data from SMEAR II, Hyytiala, Finland, Boreal Environ. Res., 10, 323-336, 2005.

Dal Maso, M., Sogacheva, L., Aalto, P. P., Riipinen, I., Komppula, M., Tunved, P., Korhonen, L., Suur-Uski, V., Hirsikko, A., Kurten, T., Kerminen, V. M., Lihavainen, H., Viisanen, Y., Hansson, H. C., and Kulmala, M.: Aerosol size distribution measurements at four Nordic field stations: identification, analysis and trajectory analysis of new particle formation bursts, Tellus B, 59, 350-361, doi:10.1111/j.1600-0889.2007.00267.x, 2007.

Draxler, R. R. and Hess, G. D.: An overview of the HYSPLIT 4 modelling system for trajectories,dispersion and deposition, Aust. Met. Mag., 47, 295-308, 1998.
Engström, A. and Magnusson, L.: Estimating trajectory uncertainties due to flow dependent errors in the atmospheric analysis, Atmos. Chem. Phys., 9, 8857-8867, doi:10.5194/acp-9-8857-2009, 2009.

Engvall, A. C., Krejci, R., Strom, J., Minikin, A., Treffeisen, R., Stohl, A., and Herber, A.: In-situ airborne observations of the microphysical properties of the Arctic tropospheric aerosol during late spring and summer, Tellus B, 60, 392-404, doi:10.1111/j.1600-0889.2008.00348.x, 2008a.

Engvall, A.-C., Krejci, R., Ström, J., Treffeisen, R., Scheele, R., Hermansen, O., and Paatero, J.: Changes in aerosol properties during spring-summer period in the Arctic troposphere, Atmos. Chem. Phys., 8, 445-462, doi:10.5194/acp-8-445-2008, 2008 b.

Fisher, J. A., Jacob, D. J., Purdy, M. T., Kopacz, M., Le Sager, P., Carouge, C., Holmes, C. D., Yantosca, R. M., Batchelor, R. L., Strong, K., Diskin, G. S., Fuelberg, H. E., Holloway, J. S., Hyer, E. J., McMillan, W. W., Warner, J., Streets, D. G., Zhang, Q., Wang, Y., and Wu, S.: Source attribution and interannual variability of Arctic pollution in spring constrained by aircraft (ARCTAS, ARCPAC) and satellite (AIRS) observations of carbon monoxide, Atmos. Chem. Phys., 10, 977-996, doi:10.5194/acp10-977-2010, 2010.

Flanner, M. G., Zender, C. S., Randerson, J. T., and Rasch, P. J.: Present-day climate forcing and response from black carbon in snow, J. Geophys. Res.-Atmos., 112, D11202, doi:10.1029/2006jd008003, 2007.

Garrett, T. J., Radke, L. F., and Hobbs, P. V.: Aerosol effects on cloud emissivity and surface longwave heating in the arctic, Journal of the Atmospheric Sciences, 59, 769-778, 10.1175/15200469(2002)059<0769:aeocea >2.0.co;2, 2002.

Garrett, T. J., Brattstrom, S., Sharma, S., Worthy, D. E. J., and Novelli, P.: The role of scavenging in the seasonal transport of black carbon and sulfate to the Arctic, Geophys. Res. Lett., 38, L16805, doi:10.1029/2011g1048221, 2011.

Guibert, S., Snider, J. R., and Brenguier, J. L.: Aerosol activation in marine stratocumulus clouds: 1. Measurement validation for a closure study, J. Geophys. Res.-Atmos., 108, 8628, doi:10.1029/2002jd002678, 2003.

Hansen, J. and Nazarenko, L.: Soot climate forcing via snow and ice albedos, P. Natl. Acad. Sci. USA, 101, 423-428, doi:10.1073/pnas.2237157100, 2004.

Hegg, D. A., Ferek, R. J., and Hobbs, P. V.: Cloud Condensation Nuclei over the Arctic-Ocean in Early Spring, J. Appl. Meteorol., 34, 2076-2082, 1995.

Heintzenberg, J., Hansson, H. C., and Lannefors, H.: The chemical composition of arctic haze at Ny-Alesund, Spitsbergen, Tellus, 33, 162-171, 1981.

Hirdman, D., Sodemann, H., Eckhardt, S., Burkhart, J. F., Jefferson, A., Mefford, T., Quinn, P. K., Sharma, S., Ström, J., and Stohl, A.: Source identification of short-lived air pollutants in the Arctic using statistical analysis of measurement data and particle dispersion model output, Atmos. Chem. Phys., 10, 669-693, doi:10.5194/acp-10-669-2010, 2010.

Hoppel, W. A. and Frick, G. M.: SSubmicron aerosol size distribution measured over the tropical and south Pacific, Atmos. Environ. A, 24, 645-659, doi:10.1016/0960-1686(90)90020-n, 1990.

$\mathrm{Hu}, \mathrm{R} . \mathrm{M}$., Blanchet, J. P., and Girard, E.: Evaluation of the direct and indirect radiative and climate effects of aerosols over the western Arctic, J. Geophys. Res.-Atmos., 110, D11213 
doi:10.1029/2004JD005043, 2005.

Hudson, S. R.: Estimating the global radiative impact of the sea ice-albedo feedback in the Arctic, J. Geophys. Res.-Atmos., 116, D16102, doi:10.1029/2011JD015804, 2011.

IPCC: Climate Change 2007: The Physical Science Basis. Contribution of Working Group I to the Fourth Assessment Report of the Intergovernmental Panel on Climate Change, edited by: Solomon, S., Qin, D., Manning, M., Chen, Z., Marquis, M., Averyt, K. B., Tignor, M., and Miller, H. L., Cambridge University Press, Cambridge, United Kingdom and New York, NY, USA, 996 pp., 2007.

Iversen, T. and Joranger, E.: Arcic air-pollution and large scale atmospheric flows, Atmos. Environ., 19, 2099-2108, doi:10.1016/0004-6981(85)90117-9, 1985.

Iziomon, M. G., Lohmann, U., and Quinn, P. K.: Summertime pollution events in the Arctic and potential implications, J. Geophys. Res.-Atmos., 111, D12206, doi:10.1029/2005JD006223, 2006.

Jaeschke, W., Beltz, N., Dierssen, J. P., Haunold, W., Krischke, U., Reinecke, A., Salkowski, T., and VonTrumbach, J.: Measurements on the distribution of trace substances in the Arctic troposphere, Atmos. Res., 44, 199-221, 1997.

Jaeschke, W., Salkowski, T., Dierssen, J. P., Trumbach, J. V., Krischke, U., and Gunther, A.: Measurements of trace substances in the Arctic troposphere as potential precursors and constituents of Arctic haze, J. Atmos. Chem., 34, 291-319, 1999.

Jokinen, V. and Makela, J. M.: Closed-loop arrangement with critical orifice for DMA sheath excess flow system, J. Aerosol Sci., 28, 643-648, 1997.

Khosrawi, F., Ström, J., Minikin, A., and Krejci, R.: Particle formation in the Arctic free troposphere during the ASTAR 2004 campaign: a case study on the influence of vertical motion on the binary homogeneous nucleation of $\mathrm{H}_{2} \mathrm{SO}_{4} / \mathrm{H}_{2} \mathrm{O}$, Atmos. Chem. Phys., 10, 1105-1120, doi:10.5194/acp-10-1105-2010, 2010.

Knutson, E. O. and Whitby, K. T.: Anomalous unipolar diffusion charging of polystryene latex spheres, Journal of Colloid and Interface Science, 53, 493-495, doi:10.1016/0021-9797(75)900673, 1975.

Koponen, I. K., Virkkula, A., Hillamo, R., Kerminen, V. M., and Kulmala, M.: Number size distributions and concentrations of the continental summer aerosols in Queen Maud Land, Antarctica, J. Geophys. Res., 108, 4587, doi:10.1029/2003JD003614, 2003.

Kulmala, M. and Kerminen, V. M.: On the formation and growth of atmospheric nanoparticles, Atmos. Res., 90, 132-150, doi:10.1016/j.atmosres.2008.01.005, 2008.

Lubin, D. and Vogelmann, A. M.: Observational quantification of a total aerosol indirect effect in the Arctic, Tellus B, 62, 181-189, 2010.

Mitchell, M.: Visual range in the polar regions with particular reference to the Alaskan Arctic, J. Atmos. Terr. Phys., Special Supplement, 195-211, 1956.

O’Neill, N. T., Pancrati, O., Baibakov, K., Eloranta, E., Batchelor, R. L., Freemantle, J., McArthur, L. J. B., Strong, K., and Lindenmaier, R.: Occurrence of weak, sub-micron, tropospheric aerosol events at high Arctic latitudes, Geophys. Res. Lett., 35, L14814, doi:10.1029/2008GL033733, 2008.

Polissar, A. V., Hopke, P. K., and Paatero, P.: Atmospheric aerosol over Alaska - 2. Elemental composition and sources, J. Geophys. Res.-Atmos., 103, 19045-19057, doi:10.1029/98jd01212, 1998.
Polissar, A. V., Hopke, P. K., and Harris, J. M.: Source regions for atmospheric aerosol measured at Barrow, Alaska, Environ. Sci. Technol., 35, 4214-4226, doi:10.1021/es0107529, 2001.

Quinn, P. K., Miller, T. L., Bates, T. S., Ogren, J. A., Andrews, E., and Shaw, G. E.: A 3-year record of simultaneously measured aerosol chemical and optical properties at Barrow, Alaska, J. Geophys. Res.-Atmos., 107, 4130, doi:10.1029/2001jd001248, 2002.

Quinn, P. K., Shaw, G., Andrews, E., Dutton, E. G., RuohoAirola, T., and Gong, S. L.: Arctic haze: current trends and knowledge gaps, Tellus B, 59, 99-114, doi:10.1111/j.16000889.2006.00238.x, 2007.

Robock, A.: Ice and Snow Feedbacks and the Latitudinal and Seasonal Distribution of Climate Sensitivity, J. Atmos. Sci., 40, 986 997, 1983.

Rosen, H., Novakov, T., and Bodhaine, B. A.: SSoot in the Arctic, Atmos. Environ., 15, 1371-1374, doi:10.1016/00046981(81)90343-7, 1981.

Sand, M., Berntsen, T. K., Kay, J. E., Lamarque, J. F., Seland, Ø., and Kirkevåg, A.: The Arctic response to remote and local forcing of black carbon, Atmos. Chem. Phys., 13, 211-224, doi:10.5194/acp-13-211-2013, 2013.

Schmale, J., Schneider, J., Ancellet, G., Quennehen, B., Stohl, A., Sodemann, H., Burkhart, J. F., Hamburger, T., Arnold, S. R., Schwarzenboeck, A., Borrmann, S., and Law, K. S.: Source identification and airborne chemical characterisation of aerosol pollution from long-range transport over Greenland during POLARCAT summer campaign 2008, Atmos. Chem. Phys., 11, 1009710123, doi:10.5194/acp-11-10097-2011, 2011.

Serreze, M. C., Holland, M. M., and Stroeve, J.: Perspectives on the Arctic's shrinking sea-ice cover, Science, 315, 1533-1536, 2007.

Sharma, S., Chan, E., Ishizawa, M., Toom-Sauntry, D., Gong, S. L., Li, S. M., Tarasick, D. W., Leaitch, W. R., Norman, A., Quinn, P. K., Bates, T. S., Levasseur, M., Barrie, L. A., and Maenhaut, W.: Influence of transport and ocean ice extent on biogenic aerosol sulfur in the Arctic atmosphere, J. Geophys. Res.-Atmos., 117, D12209, doi:10.1029/2011jd017074, 2012.

Shaw, G. E.: Eddy diffusion transport of Arctic pollution from the Mid-Latitude - A preliminary model, Atmos. Environ., 15, 1483 1490, doi:10.1016/0004-6981(81)90356-5, 1981.

Shaw, G. E.: Production of condensation nuclei in clean air by nucleation of $\mathrm{H}_{2} \mathrm{SO}_{4}$, Atmos. Environ., 23, 2841-2846, doi:10.1016/0004-6981(89)90564-7, 1989.

Shaw, G. E.: The arctic haze phenomenon, B. Am. Meteorol. Soc., 76, 2403-2413, 1995.

Shindell, D. and Faluvegi, G.: Climate response to regional radiative forcing during the twentieth century, Nature Geosci., 2, 294-300, doi:10.1038/ngeo473, 2009.

Shupe, M. D. and Intrieri, J. M.: Cloud radiative forcing of the Arctic surface: The influence of cloud properties, surface albedo, and solar zenith angle, J. Climate, 17, 616-628, doi:10.1175/15200442(2004)017;0616:crfota;2.0.co;2, 2004.

Snider, J. R., Guibert, S., Brenguier, J. L., and Putaud, J. P.: Aerosol activation in marine stratocumulus clouds: 2 . Kohler and parcel theory closure studies, J. Geophys. Res.-Atmos., 108, 8629, doi:10.1029/2002jd002692, 2003.

Stohl, A.: Characteristics of atmospheric transport into the Arctic troposphere, J. Geophys. Res.-Atmos., 111, D11306, doi:10.1029/2005jd006888, 2006. 
Stohl, A., Berg, T., Burkhart, J. F., Fjæraa, A. M., Forster, C., Herber, A., Hov, Ø., Lunder, C., McMillan, W. W., Oltmans, S., Shiobara, M., Simpson, D., Solberg, S., Stebel, K., Ström, J., Tørseth, K., Treffeisen, R., Virkkunen, K., and Yttri, K. E.: Arctic smoke - record high air pollution levels in the European Arctic due to agricultural fires in Eastern Europe in spring 2006, Atmos. Chem. Phys., 7, 511-534, doi:10.5194/acp-7-511-2007, 2007.

Strom, J., Umegard, J., Torseth, K., Tunved, P., Hansson, H. C., Holmen, K., Wismann, V., Herber, A., and Konig-Langlo, G.: One year of particle size distribution and aerosol chemical composition measurements at the Zeppelin Station, Svalbard, March 2000-March 2001, Phys. Chem. Earth, 28, 1181-1190, doi:10.1016/j.pce.2003.08.058, 2003.

Strom, J., Engvall, A. C., Delbart, F., Krejci, R., and Treffeisen, R.: On small particles in the Arctic summer boundary layer: observations at two different heights near Ny-Alesund, Svalbard, Tellus B, 61, 473-482, doi:10.1111/j.1600-0889.2008.00412.x, 2009.

Textor, C., Schulz, M., Guibert, S., Kinne, S., Balkanski, Y., Bauer, S., Berntsen, T., Berglen, T., Boucher, O., Chin, M., Dentener, F., Diehl, T., Easter, R., Feichter, H., Fillmore, D., Ghan, S., Ginoux, P., Gong, S., Grini, A., Hendricks, J., Horowitz, L., Huang, P., Isaksen, I., Iversen, I., Kloster, S., Koch, D., Kirkevåg, A., Kristjansson, J. E., Krol, M., Lauer, A., Lamarque, J. F., Liu, X., Montanaro, V., Myhre, G., Penner, J., Pitari, G., Reddy, S., Seland, $\varnothing .$, Stier, P., Takemura, T., and Tie, X.: Analysis and quantification of the diversities of aerosol life cycles within AeroCom, Atmos. Chem. Phys., 6, 1777-1813, doi:10.5194/acp-6-1777-2006, 2006.

Tunved, P., Ström, J., and Hansson, H.-C.: An investigation of processes controlling the evolution of the boundary layer aerosol size distribution properties at the Swedish background station Aspvreten, Atmos. Chem. Phys., 4, 2581-2592, doi:10.5194/acp-4-2581-2004, 2004.
Twomey, S.: Influence of polltuion on shortwave albedo of clouds, J. Atmos. Sci., 34, 1149-1152, doi:10.1175/15200469(1977)034<1149:tiopot>2.0.co;2, 1977.

Van Dingenen, R., Raes, F., Putaud, J. P., Baltensperger, U., Charron, A., Facchini, M. C., Decesari, S., Fuzzi, S., Gehrig, R., Hansson, H. C., Harrison, R. M., Huglin, C., Jones, A. M., Laj, P., Lorbeer, G., Maenhaut, W., Palmgren, F., Querol, X., Rodriguez, S., Schneider, J., ten Brink, H., Tunved, P., Torseth, K., Wehner, B., Weingartner, E., Wiedensohler, A., and Wahlin, P.: A European aerosol phenomenology-1: physical characteristics of particulate matter at kerbside, urban, rural and background sites in Europe, Atmos. Environ., 38, 2561-2577, doi:10.1016/j.atmosenv.2004.01.040, 2004.

Wang, M. Y. and Overland, J. E.: A sea ice free summer Arctic within 30 years?, Geophys. Res. Lett., 36, L18501, doi:10.1029/2012GL052868, 2009.

Warneke, C., Bahreini, R., Brioude, J., Brock, C. A., de Gouw, J. A., Fahey, D. W., Froyd, K. D., Holloway, J. S., Middlebrook, A., Miller, L., Montzka, S., Murphy, D. M., Peischl, J., Ryerson, T. B., Schwarz, J. P., Spackman, J. R., and Veres, P.: Biomass burning in Siberia and Kazakhstan as an important source for haze over the Alaskan Arctic in April 2008, Geophys. Res. Lett., 36, L02813, doi:10.1029/2008GL036194, 2009.

Weber, R. J., Orsini, D., Wang, B., Scheuer, E., Talbot, R. W., Dibb, J. E., Seid, G. K., DeBell, L., Mauldin, R. L., Kosciuch, E., Cantrell, C., and Eisele, F.: Investigations into free tropospheric new particle formation in the central Canadian arctic during the winter/spring transition as part of TOPSE, J. Geophys. Res.-Atmos., 108, 8357, doi:10.1029/2002JD002239, 2003. 